\title{
A review of research-supported group treatments for drug use disorders
}

\author{
Gabriela López ${ }^{1}$, Lindsay M. Orchowski ${ }^{2^{*}}$ (D, Madhavi K. Reddy ${ }^{3}$, Jessica Nargiso ${ }^{4}$ and Jennifer E. Johnson ${ }^{5}$
}

\begin{abstract}
This paper reviews methodologically rigorous studies examining group treatments for interview-diagnosed drug use disorders. A total of 50 studies reporting on the efficacy of group drug use disorder treatments for adults met inclusion criteria. Studies examining group treatment for cocaine, methamphetamine, marijuana, opioid, mixed substance, and substance use disorder with co-occurring psychiatric conditions are discussed. The current review showed that cognitive behavioral therapy (CBT) group therapy and contingency management (CM) groups appear to be more effective at reducing cocaine use than treatment as usual (TAU) groups. CM also appeared to be effective at reducing methamphetamine use relative to standard group treatment. Relapse prevention support groups, motivational interviewing, and social support groups were all effective at reducing marijuana use relative to a delayed treatment control. Group therapy or group CBT plus pharmacotherapy are more effective at decreasing opioid use than pharmacotherapy alone. An HIV harm reduction program has also been shown to be effective for reducing illicit opioid use. Effective treatments for mixed substance use disorder include group CBT, CM, and women's recovery group. Behavioral skills group, group behavioral therapy plus CM, Seeking Safety, Dialectical behavior therapy groups, and CM were more effective at decreasing substance use and psychiatric symptoms relative to TAU, but group psychoeducation and group CBT were not. Given how often group formats are utilized to treat drug use disorders, the present review underscores the need to understand the extent to which evidencebased group therapies for drug use disorders are applied in treatment settings.
\end{abstract}

Keywords: Treatment, Substance use disorders, Group, Group therapy, Review

\section{Background}

Drug use disorders are a significant public health concern in the United States. According to the National Epidemiologic Survey of Alcohol and Related Conditions-III, the lifetime prevalence rate of DSM- 5 drug use disorders is 9.9\%, which includes amphetamine, cannabis, club drug, cocaine, hallucinogen, heroin, opioid, sedative/tranquilizer, and solvent/inhalant use disorders [1]. Drug use disorders are defined in terms of eleven criteria including physiological, behavioral and cognitive symptoms, as well as consequences of criteria, any two of which qualify for a

\footnotetext{
*Correspondence: Lindsay_Orchowski@Brown.edu

${ }^{2}$ Alpert Medical School of Brown University, Department of Psychiatry and Human Behavior, Providence, RI 02904, USA

Full list of author information is available at the end of the article
}

diagnosis $[2,3]$. The individual and community costs of drug use are estimated at over $\$ 193$ billion $[4,5]$ and approximately $\$ 78.5$ billion [6] for opioids alone. Consequences include overdose [7], mental health problems [8], and a range of medical consequences such as human immunodeficiency virus $[9,10]$, hepatitis $C$ virus [9], and other viral and bacterial infections [11].

Evidence-based practice was formally defined by Sackett et al. [12] in 1996 to refer to the "conscientious, explicit, and judicious use of current best evidence in making decisions about the care of individual patients" (p. 71). In 2006, the American Psychological Association [13] developed a policy on evidence-based practice (EBP) of psychotherapy, which emphasized the integration of best research evidence (i.e., data from meta-analyses, randomized controlled trials, 
effectiveness trials, and other forms of systematic case studies and reviews) with clinical expertise and judgment to deliver treatment in the context of a patient's individual needs, preferences and culture. The shift towards EBP for substance use disorders has multiple benefits for practitioners and patients, including an increased focus on the implementation of treatments that are safe and cost-effective [14]. A recent survey of clinicians' practices with substance use treatment found that clinicians often conducted therapy in groups [15]. While most clinicians who completed the survey reported use of evidence-based treatment practices (EBT) some also reported the use of non-EBT practices [15]. Ensuring that clinicians can readily access information regarding the current state of evidence regarding group-based therapies for substance use disorders is critical for fostering increased use of EBTs.

Although any effort to summarize a literature as large and complex as the psychological treatment literature is useful, there are several limitations. With few exceptions, research-supported treatment lists categorize treatments by formal change theory (e.g., cognitive-behavioral, interpersonal) and describe little about the context, format, or setting in which treatments were conducted and tested [16]. As a result, it is often difficult to ascertain from existing resources whether research supported treatments were conducted in group or individual format. A group format is often used in substance use treatment [17] and aftercare programs [18-22]. The discrepancy between the wide-spread use of group therapy in clinical practice and the relative paucity of research on the efficacy of group treatments has been noted by treatment researchers [23] and clinicians [24]. According to Lundahl's [25] 2010 meta-analysis of studies evaluating the efficacy of motivational interviewing (MI), a commonly used treatment for substance use disorders, examination of the 119 studies concluded that studies of MI in a group format were too rare to draw solid conclusions about the efficacy of group MI. Also, it is possible that efficacy of treatments developed for individual delivery will be altered when delivered in a group format and vice versa. Given the limited empirical inquiry on group treatments for substance use, a framework organizing the literature on the efficacy of group therapy to treat substance use disorders would be useful. There is also a need for a more recent rigorous review of the empirical evidence to support group-based treatments for substance use disorders. Over 15 years ago, Weiss and colleagues conducted a review of 24 treatment outcome studies within the substance use disorder intervention literature comparing group therapy to other treatments conditions (i.e., no group therapy, individual therapy, group therapy plus individual therapy), and found no differences between group and individual therapy [26].

Given the importance of understanding the current evidence base for group-delivered treatments for substance use disorders, the present review sought to provide a summary of the literature on the benefits of group treatments for drug use disorders. Group treatments are potentially cost-effective, widely disseminable, and adaptable to a variety of populations but are lagging individual treatments in terms of research attention. Thus, highlighting characteristics of group treatments that are potentially efficacious is of import to stimulate further empirical inquiry. The review is organized by drug type (cocaine, methamphetamine, marijuana, opiate, mixed substance use disorders; SUD) and cooccurring SUD and psychiatric problems. We excluded studies focused on alcohol use disorder alone as this literature is summarized elsewhere (see Orchowski \& Johnson, 2012). Given research suggesting that several factors impact outcomes of group treatments, including formal change theory driving the treatment approach (i.e., cognitive-behavioral, motivational interviewing), as well as patient factors [27], the review begins by first reviewing each theory of change (i.e., type of treatment), and then concludes by summarizing the research examining the extent to which patient factors influence the efficacy of group treatments for SUD.

\section{Method}

To locate studies that evaluated a group treatment for SUD that met review inclusion criteria, the authors conducted a comprehensive literature search of PsycINFO and MedLine through 2020. Three individuals then examined abstracts of the articles for relevance. In addition, the authors utilized the reference lists of review studies and meta-analyses of SUD- treatments to locate additional studies that might meet the review inclusion criteria. The authors and a research assistant then reviewed full articles with relevance to the current study and excluded any studies that did not meet the review inclusion criteria (see Fig. 1).

For inclusion in the review, studies needed to meet the following criteria: 1) report the findings of at least one group treatment; 2) provide at least one statistical comparison between the group treatment and a control condition; 3) randomize participants between the group treatment and control condition; 4) utilize a manualized treatment; 5) include patients with an interviewdiagnosed SUD; and 6) provide information regarding the demographic characteristics of the participants in the study. Studies' methods and results were used for data extraction. Studies which maintained a primary focus on the treatment of SUD, but also included treatment of a co-occurring psychiatric condition, were included in the review. Studies which included alcohol use as a comorbid diagnosis along another substance use were included. Studies examining the efficacy of group treatment for only alcohol use were excluded. The final 


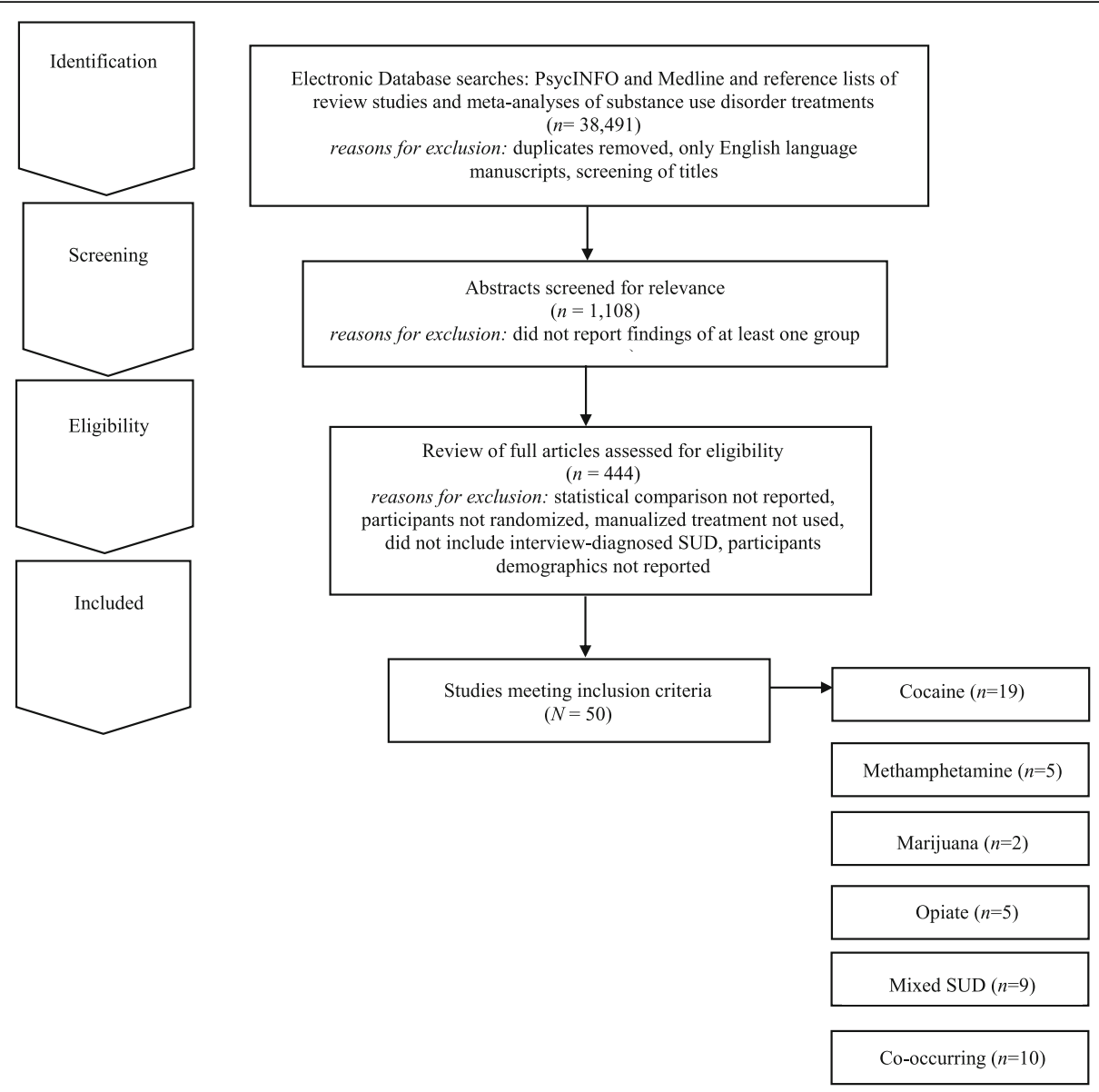

Fig. 1 Electronic Search Strategy Flowchart

set of articles included were 50 research studies that utilized a group treatment modality for the treatment of SUD, including separately examining cocaine, methamphetamine, marijuana, opioid, mixed substance, or SUD with comorbid psychiatric problems in adults.

It should be noted that several studies that met inclusion criteria were not reported in the present review because they did not report the use of a specific screening instrument for SUD as a part of the study inclusion/exclusion criteria. These studies are as follows and include these comparisons: group-based relational therapy [28] two studies by Guydish et al. [29, 30] comparing a day treatment program to residential treatment (RT) program, a day treatment program to a coping skills group [31], standard care to a harm reduction group [32], 12 step group to a CBT group [33], medical management treatment (MMT) with CBT group to an MMT plus treatment reinforcement plan [34], treatment as usual to contingency management (CM) [35], professionally led recovery training group to treatment as usual (TAU) [36], two 4 month residential treatment programs [37], varying lengths of therapeutic community program
(TPC) with and without relapse prevention [38], and Information and Referral plus peer advocacy to a Motivational group with CBT group [39].

\section{Review of evidence-based theories of change}

The 50 research studies meeting inclusion criteria tested the following group treatment modalities: contingency management $(\mathrm{CM})$, motivational interviewing (MI), relapse prevention (RP), social support (SS), cognitivebehavioral (CBT), coping skills (CS), harm reduction (HR), cognitive therapy (CT), drug counseling (DC), recovery training (RT), standard group therapy (SGT), family therapy (FT), intensive group therapy (IGT), 12 step facilitation group therapy (12SG), relational psychotherapy mothers' group (RPMG), psychoeducational therapy group (PET), behavioral skills (BS), and seeking safety (SS). Below, we briefly review the theory of change that drives each of these treatments.

Several treatment approaches are grounded in behavioral therapies and/or cognitive therapies. Broadly, cognitive therapy is an approach that focuses exclusively on targeting thoughts that are identified as part of a 
diagnosis or behavioral problem [28]. Cognitivebehavioral (CBT) therapy is an approach that targets specific symptoms, thoughts, and behaviors that are identified as part of a diagnosis or presenting problem [28]. Under the umbrella of CBT several other treatment modalities exist. For example, relapse prevention is a CBT treatment that hypothesizes that there are cognitive, behavioral, and affective mechanism that underlie the process of relapse [40]. Recovery training is a more specific form of relapse prevention, including education on addiction and recovery and reinforcing relapse prevention skills (e.g., understanding triggers, coping with cravings etc.) $[41,42]$. Other treatments focus on coping skills more broadly. For example, coping skills treatments include a focus on components of adaptability in interpersonal relationships, thinking and feeling, as well as approaches to self and life [28]. Some treatment approaches also recognize that individuals may not be ready to change their substance use. For example, motivational interviewing is often described as a therapy guiding technique in which the therapist is a helper in the behavior change process and expressed acceptance of the patient [43]. Standard group therapy includes $90 \mathrm{~min}$ sessions approximately twice a week in a group setting, [44] whereas intensive group therapy is a heavier dose of standard group therapy that includes 120-min sessions up to five times a week [44]. Psychoeducational therapy group focused on providing information on the immediate and delayed problems of substance use disorders to patients [45]. Lastly, dialectical behavior therapy (DBT) is a type of CBT therapy that focuses on helping regulate intense emotional states and provides skills to reduce arousal levels, and increase mindfulness, emotional regulation, and interpersonal skills [46].

Grounded within behavioral therapies, are behavioral skills training which focused on developing behaviors that are adaptive [28]. Contingency management is a type of behavioral therapy in which patients are reinforced or rewarded for positive behavioral change [47]. Harm reduction is a term for interventions aiming to reduce the problematic effects of behaviors [48]. Several treatment approaches also focus on interpersonal networks and building interpersonal skills. For example, social support is any psychological resources provided by a social network to help patients cope with stress [49]. Twelve-step facilitation group therapy is a more specific form of social support, which focuses on introducing patients to the 12 steps of alcoholics anonymous or related groups (i.e., cocaine or narcotics anonymous) to encourage 12-step meeting attendance in their community [33, 50]. Seeking Safety is a present-focused and empowerment-based intervention focused on coping skills that emphasizes the importance of safety within interpersonal relationships [51]. Drug counseling describes treatment that aims to facilitate abstinence, encourage mutual support, and provide coping skills [52]. Finally, family therapy is a family-based intervention that aims to change, parenting behaviors and family interactions [53]. Overall, there are many overlapping components and skill sets in the models discussed above (See Table 1).

\section{Group-based cocaine use treatments for adults}

Nineteen studies were identified that targeted cocaine use and utilized some form of group therapy, the most of any drug in this review (see Table 2). Overall, the studies showed that all of the group therapy modalities included in this review generally reduced cocaine use when compared to treatment as usual (TAU), including day hospital groups [54]. Two studies, Magura et al. (1994) and Magura et al. (2002) did not find group differences between 8 months CBT and 8 months of TAU that consisted of methadone maintenance therapy among 141 patients with cocaine disorder [60, 69]. When compared directly, individuals in CBT groups achieved longer abstinence than individuals in 12 step facilitation groups [33] or low intensity groups [64, 65]. However, in another study, individuals with cocaine dependence receiving 12-step based Group Drug Counseling (GDC; similar to 12-step facilitation) had similar cocaine abstinence outcomes with or without additional individual CBT [41]. This may suggest that group 12step facilitation is an effective intervention for cocaine dependence. Two studies demonstrated the superiority of CM groups for reducing cocaine use as compared to

Table 1 Therapy subtypes organized by theories of change

\begin{tabular}{lll}
\hline Cognitive Behavioral Therapy & Behavioral Therapy & Interpersonal Skills Therapy \\
\hline Relapse Prevention & Behavioral skills & Social Support \\
Recovery Training & Contingency Management & Twelve Step Group Therapy \\
Coping Skills & Harm Reduction & Seeking Safety \\
Motivational Interviewing & & Family Therapy \\
Standard Group Therapy & & Drug Counseling \\
Psychoeducational Therapy & & \\
Dialectical Behavior Therapy & & \\
\hline
\end{tabular}


Table 2 Summary of evidence-based cocaine use group treatment for adults

\begin{tabular}{|c|c|c|c|c|c|}
\hline Study & Patient Characteristics $^{\mathrm{a}}$ & Treatment Description & Manual & Study Characteristics ${ }^{b, c}$ & Results \\
\hline $\begin{array}{l}\text { Coviello } \\
\text { et al., } 2001 \\
{[54]}\end{array}$ & $\begin{array}{l}94 \text { veterans with } C D(D I S) \\
\text { and without psychiatric or } \\
\text { medical instability. Mean age } \\
40 \text { years, } 0 \% \text { female, } 92 \% \\
\text { African American. }\end{array}$ & $\begin{array}{l}\text { 4-weeks: } \\
\text { 1. } 12 \text {-h per weekday hospital } \\
\text { program (DH12; } 12 \text {-h abbrevi- } \\
\text { ated version of a } 27-\mathrm{h} \text { a } \\
\text { weekday hospital program, } \\
\text { with } 7 \mathrm{~h} \text { of group treatment, } \\
3 \mathrm{~h} \text { of educational therapy } \\
\text { and } 2 \mathrm{~h} \text { of counseling and } \\
\text { case management over five } \\
\text { weekdays). } \\
\text { 2. 6-h per week outpatient } \\
\text { program (OP6; 6-h of } \\
\text { groups, } 1 \mathrm{~h} \text { of educational } \\
\text { therapy and } 1 \mathrm{~h} \text { of } \\
\text { counseling and case } \\
\text { management over three }\end{array}$ & $\begin{array}{l}\text { 1. Yes } \\
\text { 2. Yes }\end{array}$ & $\begin{array}{l}\text { RAAT; } 4-\text { and } 7-\text { month f/u. } \\
\text { 93\% f/u rate; } 39 \% \text { tx } \\
\text { completion. }\end{array}$ & $\begin{array}{l}\text { Across groups, patients } \\
\text { reported a } 52 \% \text { reduction in } \\
\text { days of cocaine use and } \\
\text { experienced significant } \\
\text { improvements in } \\
\text { employment and psychiatric } \\
\text { functioning at 7-month f/u. } \\
\text { No difference between DH12 } \\
\text { and OP6 programs in terms } \\
\text { of abstinence during treat- } \\
\text { ment, treatment completion, } \\
\text { treatment or aftercare attend- } \\
\text { ance or any Addiction Sever- } \\
\text { ity Index (ASI)-related variable } \\
\text { at 4- and 7-month f/u. }\end{array}$ \\
\hline
\end{tabular}

Crits- $\quad 487$ solicited with CD

Christoph (Anxiety Disorders Interview

et al., 1999 Schedule). Mean age 34

[41]; years, $23 \%$ female, $40 \%$

Crits- African American.

Christoph

et al., 2001

[55];

Siqueland

et al., 2002

[56]

\section{management over three} weekdays).

24 weekly group sessions for 1. Yes $90 \mathrm{~min}, 36$ individual sessions 2. Yes for 50 min, plus 3 monthly 3. Yes booster sessions:

3. Yes

1. Manual guided group drug

counseling (GDC; [57])

2. GDC plus individual

supportive-expressive therapy (GDC + SE; [58])

3. GDC plus individual cognitive therapy $(\mathrm{GDC}+\mathrm{CT})$

4. GDC plus 12-step individual drug counseling (GDC + IDC)
RAAT; 3-, 6-, 9-, and 12$31 \%$ tx completion. month $\mathrm{f} / \mathrm{u}$. $100 \% \mathrm{f} / \mathrm{u}$ rate.

$I D C+G D C$ reduced drug composite score more than other treatments over 9- and 12 -month $\mathrm{f} / \mathrm{u}$. No differences revealed between GDC or $\mathrm{GDC}+\mathrm{SE}$ or GDC + CT. Superiority of IDC + GDC vs. others did not extend to other addiction associated problems. $\mathrm{IDC}+\mathrm{GDC}$ stayed in treatment for fewer days than others but were more likely to be abstinent after dropout. Younger, African American, and unemployed patients were retained in treatment for fewer days than others. Higher psychiatric severity kept men in treatment longer but increased women's risk for drop out. Higher psychiatric severity increased risk for continuing to use drugs after dropout.

RAWC; 12 - week f/u. 63\% of control completed $f / u, 62 \%$ of CM completed $f / u, 58 \%$ of individual counseling for $29 \quad$ 2. Yes weeks, with baseline $\quad$ 2. No treatment (5 weeks), intervention (12 weeks), and maintenance therapy (12 weeks):

1. Voucher condition (CM; depressive disorders, $A D$, or sedative dependence, medical conditions, pregnancy, cognitive impairment, or and urologic conditions that would preclude urine collection. Mean age of 29 years, 43\% female, $70 \%$ African American.
(Control; CBT completed f/u, and 57\% but Yes, of CM-CBT completed f/u. for $\mathrm{CM}$ ) $76 \%$ of control completed tx, 4. No $81 \%$ of CM completed tx, $79 \%$ of CBT completed tx, and $69 \%$ of CM-CBT completed $t x$.
During treatment, initial effects of CM were dampened by CBT. Posttreatment CM-CBT evidenced positive results compared to others over 12month f/u. CBT participants were also more likely to acknowledge cocaine use and its effects and to report employment.
Hoffman et al., 1996
184 referred individuals with cocaine abuse/CD (CIDI and DIS), without dependency on other drugs, or psychosis. Mean age 32 years, $40 \%$ female, 95\% African contingent on cocaine-

negative urine or

noncontingent).

2 CM plus CBT based group

therapy (CM-CBT; 1x week,

90 min for 12 weeks)

3. Cognitive behavioral group (CBT; 1x week, 90 min for 12 weeks)

4. Control condition (Control;

Social support group, $1 \mathrm{x}$ week, 90 min for 12 weeks)

4-months with up to $4 \quad$ 1. Yes vocational assessment/ 2. Yes therapy sessions on an 3. Yes individual basis, and up to 4 4. Yes family group therapy sessions 5 . Yes once a month):
RAAT; 12 -month f/u, 66\% 12month f/u rate. Tx completion rates were: $19.1 \%$ SGT only, 38.5\% SGT + IT, 46.8\% $\mathrm{SGT}+\mathrm{IT}+\mathrm{FT}, 45.2 \%$ IGT only, $34.3 \% \mathrm{IGT}+\mathrm{IT}$, and $38.5 \%$
Across groups, patients evidenced significant prepost treatment gains: reduced regular cocaine use, reduced other drug use, reduced regular alcohol use, 
Table 2 Summary of evidence-based cocaine use group treatment for adults (Continued)

\begin{tabular}{|c|c|c|c|c|c|}
\hline Study & Patient Characteristics $^{\mathrm{a}}$ & Treatment Description & Manual & Study Characteristics ${ }^{\mathrm{b}, \mathrm{c}}$ & Results \\
\hline & American. & $\begin{array}{l}\text { 1. Standard Group Therapy } \\
\text { (SGT; } 90 \text {-min, } 2 \text { sessions per } \\
\text { week) with Individual Therapy } \\
\text { (IT; } 60 \text { min, } 2 \text { sessions per } \\
\text { week starting month } 1 \text { and } 1 \\
\text { session thereafter) (SGT + IT) } \\
\text { 2. SGT + IT plus Family } \\
\text { Therapy (FT; } 90 \text {-min sessions, } \\
\text { 1 session per week starting in } \\
\text { month 2) (SGT + IT+FT) } \\
\text { 3. SGT only }\end{array}$ & 7. Yes & IGT + IT+FT. & $\begin{array}{l}\text { and reduced involvement in } \\
\text { illegal activities. Regular co- } \\
\text { caine users over } 12 \text {-month f/ } \\
\text { u were more likely to be fe- } \\
\text { male, less educated, have } \\
\text { been using cocaine prior to } \\
\text { treatment, spent fewer days } \\
\text { incarcerated during 12- } \\
\text { months post treatment, and } \\
\text { have attended fewer treat- } \\
\text { ment sessions. }\end{array}$ \\
\hline
\end{tabular}

McKay 132 veterans referred from

et al., 1997 intensive outpatient

[21]; $\quad$ treatment with CD $(\mathrm{SCID})$.

McKay Mean age 40 years, $0 \%$

et al., 1999 female, 85\% African

[20] American.
4. Intensive Group Therapy

(IGT; 120-min, 5 sessions per

week) with IT (IGT + IT)

5. IGT + IT+FT

6. IGT only

\section{2 sessions per week for 5} months:

1. Standard aftercare group

(ST; addiction counseling and

12-step based)

2. Individual relapse prevention (RP; 1 weekly ST group plus 1 session individual therapy, selfefficacy focused)

\begin{abstract}
Magura
141 patients in methadone

8 months of treatment:

1. Cognitive behavioral

et al., 1994 maintenance treatment with

[60]; $\mathrm{CD}$ (SCID). Mean age 39

Magura, years, 33\% female, $26.2 \%$

et al., 200,

256)

African American, 39.7\%

Hispanic. therapy plus treatment reinforcement plan (CBT; Matrix model; In Phase I, subjects participated in a 4month CBT program with two individual and three group sessions per week. Phase II consisted of two group sessions per week. 2. Treatment as usual (TAU; standard methadone maintenance therapy)
\end{abstract}

Petry et al., 387 patients in intensive 2007 [61] outpatient with cocaine abuse or CD (SCID) and without psychosis, suicidal, or pathological gambling. Mean age 36 years, $50 \%$ female, 51\% African American. 12-weeks:

1. Treatment as usual (TAU)

2. TAU plus contingency

management ( $\mathrm{CM}$; chance to earn prizes or vouchers for submitting negative samples and/or completing goalrelated activities)
1. Yes

2. No

RAWC across tx site ( 2 sites offered CBT, 2 sites TAU); 4and 12 -month f/u. $76 \% 12-$ month f/u rate. For CBT 56\% tx completion for Phase I and $51 \%$ tx completion for Phase II.
1.No

2. Yes

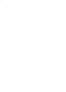

RAWC; Months 1, 3, 6, and 9 $\mathrm{f} / \mathrm{u}, 84.2,81.2,73.5$, and $69.0 \%$ f/u rates at months $1,3,6$, and 9 . Tx completion rate not reported.

\section{$\begin{array}{ll}\text { 1. No } & \text { RAAT. } 2-y r \text { f f/u, } 92 \% \text { follow- } \\ \text { 2. Yes } & \text { rate, } 43 \% \text { tx completion. }\end{array}$}

Complete abstinence rates favored ST but RP was more effective in limiting extent of cocaine use. Self-efficacy predicted cocaine use. Patients reporting commitment to absolute abstinence had better cocaine use outcomes in RP compared to ST. Patients reporting less stringent abstinence goals had better cocaine use outcomes in ST compared to RT. Patients with $C D$ or $A D$ upon entering tx who received RP had better cocaine use outcomes in Months 1-6 and better alcohol use outcomes in Months 13-24 than those in ST. At 2 years, medical outcomes were significantly better for RT compared to ST.

Cocaine use declined significantly from baseline to 4- and 12-month f/u across groups. CBT participants rated the quality of their counseling relationship higher and obtained more supportive services than TAU. Group was not associated with outcome. Measures associated with poorer outcomes across both groups were: currently enrolled in methadone treatment, higher cocaine use frequency, greater cocaine use associated problem recognition, and an ambivalence toward methadone treatment.

Quality of life (QOLI) scores over time differed by group, with QOLI scores rising over time in CM participants and remaining stable in TAU. CM achieved greater durations of abstinence, and duration of abstinence was correlated with post treatment QOLI. Abstinence mediated the 
Table 2 Summary of evidence-based cocaine use group treatment for adults (Continued)

\begin{tabular}{|c|c|c|c|c|c|}
\hline Study & Patient Characteristics $^{\mathrm{a}}$ & Treatment Description & Manual & Study Characteristics ${ }^{\mathrm{b}, \mathrm{c}}$ & Results \\
\hline & & & & & $\begin{array}{l}\text { relationship between } \\
\text { treatment condition and } \\
\text { QOLI over time. }\end{array}$ \\
\hline $\begin{array}{l}\text { Rawson } \\
\text { et al., } 2002 \\
{[62]}\end{array}$ & $\begin{array}{l}120 \text { patients in methadone } \\
\text { maintenance program with } \\
\text { CD (SCID). Mean age } 43 \text { years } \\
\text { of age, 32\% African } \\
\text { American, } 26 \% \text { Hispanic. }\end{array}$ & $\begin{array}{l}\text { 16-weeks: } \\
\text { 1. Contingency Management } \\
\text { (CM; vouchers for stimulant- } \\
\text { free urine samples; three } \\
\text { samples per week and meet } \\
\text { briefly with the CM } \\
\text { technician) } \\
\text { 2. CBT group (CBT; three 90- } \\
\text { min group sessions each } \\
\text { week, for } 16 \text { weeks). } \\
\text { 3. CM plus CBT groups (CM- }\end{array}$ & $\begin{array}{l}\text { 1. Yes } \\
\text { 2. Yes } \\
\text { 3. Yes } \\
\text { 4. No }\end{array}$ & $\begin{array}{l}\text { RAAT; } 17,26 \text { and } 52 \text { weeks, } \\
80 \% \text { follow-up rate, tx com- } \\
\text { pletion not reported. }\end{array}$ & $\begin{array}{l}\text { Two CM groups had superior } \\
\text { urine analysis results } \\
\text { compared to CBT and TAU at } \\
16 \text { weeks. At week } 17 \text { all } \\
\text { groups but TAU evidenced } \\
\text { reduced rates of cocaine use. } \\
\text { At } 26 \text { and } 52 \text { week f/u CBT } \\
\text { showed improvement, } \\
\text { gaining equivalence to CM } \\
\text { groups in urine analysis and } \\
\text { cocaine use. }\end{array}$ \\
\hline
\end{tabular}

Rohsenow 128 recruited patients in et al., 2000 private substance abuse [34]; treatment facilities with CD Rohsenow (SCID). Mean age 28 years, et al., $2001 \quad 31 \%$ female, $8 \%$ African [63] American.
CBT; separate sessions) 4. Treatment as usual (TAU; methadone maintenance clinic)

Up to eight 45-min individual 1. Yes sessions held three to five 2. Yes times per week:

1. Meditation-relaxation training (MRT; Control). 2. Cocaine specific coping skills treatment (CST).
Rosenblum et al., 1995 [64]; Rosenblum et al., 1999 [65]
198 methadone patients with 26 weeks: CD (SCID), stabilized methadone dose without psychosis or medical condition. Mean age 38 years, $43 \%$ female, over $50 \%$ Hispanic.
1. Cognitive behavioral therapy (CBT; Matrix model; 5 days per week, $30 \mathrm{~min}$ individual and $45 \mathrm{~min}$. Group sessions. During week 1-4, 3 individual and 2 group sessions, at week 5, 2 individual sessions and 3 group sessions) 2. Low intensity therapy (LIT; weekly group)

(1)

es

month f/u rate, $90.4 \% 15-$
month f/u rate. $60 \%$ tx
month $\mathrm{f} / \mathrm{u}$ rate. $60 \%$ tx completion.

RAWC; 3-, 6- and 9-month f/ u., $79 \% \mathrm{f} / \mathrm{u}$ rate, $84 \%$ tx completion $(N=108)$.

$$
\text { completion. }
$$

RAAT; 12-month f/u, 50\% completed PET, and $40 \%$ completed CM. f/u rates not reported.

Group therapy sessions (GDC) 1. No available 5 days per week, 2. Yes expected to attend 2 sessions per week, plus:

1. Case management $(\mathrm{CM} 1$

15-min session weekly)

2. Psychologically enhanced

program (PET access to parenting classes, GED

classes, access to a staff psychiatrist, and unlimited access to an individual therapist)

Weinstein, 447 referred patients with CD Weekly sessions for 12 weeks. 1. No et al. (1997) (screened via Risky AIDS [67]; $\begin{array}{ll}\text { Gottheil } & \text { psychotic, suicidal or } \\ \text { et al. (1998) } & \text { cognitively impaired. Mean }\end{array}$ Behavior Inventory), and not $\begin{array}{ll}\text { 1. Individual counseling (IC, } 1 & \text { 2. No }\end{array}$

h; supportive, expressive, $\quad$ 3. No problem focused) 2. Individual counseling (1 h)
RAAT; 6-month and 9-month $\mathrm{f} / \mathrm{u}, 70 \%$ of IC completed $\mathrm{f} / \mathrm{u}$, $72 \%$ of IC-G completed $\mathrm{f} / \mathrm{u}$ and $70 \%$ of IT completed $\mathrm{f} / \mathrm{u}$. $20 \%$ of IC and IC-G
CST participants who relapsed had significantly fewer cocaine use days than did the control group during the first 6 months $f / u$, no differences over 9-month $\mathrm{f} / \mathrm{u}$. CST drank alcohol more frequently during 6 months $\mathrm{f} / \mathrm{u}$ than MRT. No differences in heavy drinking days. No interaction of treatment was found with gender, education, route of administration, drug use severity, sociopathy, or depression.

Both groups showed significant and equivalent reductions in cocaine use. Completing tx and lower cocaine severity at baseline were associated with lower proportion of cocainepositive urines over f/u. Highseverity patients improved more in CBT compared to LIT. Positive outcomes for therapy completers relative to noncompleters increased over time.

Program retention was better for patients in PET. Mean number of days of cocaine use decreased from baseline in both groups, and PET had fewer days of cocaine use at 12-month f/u than CM.

IT evidenced improvement on addiction severity, depression and psychiatric symptoms at end of tx. Regardless of group, at 9- 
Table 2 Summary of evidence-based cocaine use group treatment for adults (Continued)

\begin{tabular}{|c|c|c|c|c|c|}
\hline Study & Patient Characteristics $^{\mathrm{a}}$ & Treatment Description & Manual & Study Characteristics ${ }^{\mathrm{b}, \mathrm{c}}$ & Results \\
\hline [68]. & $\begin{array}{l}\text { age of } 32 \text { years, } 44 \% \text { female, } \\
93 \% \text { African American. }\end{array}$ & $\begin{array}{l}\text { plus } 1 \text { weekly group session } \\
\text { (1 h) (IC-G) } \\
\text { 3. Intensive Treatment group } \\
\text { (IT; } 3 \text {-hours of group, } 3 \\
\text { times per week). }\end{array}$ & & $\begin{array}{l}\text { completed } t x \text {, and } 32 \% \text { of IT } \\
\text { completed } t x \text {. }\end{array}$ & $\begin{array}{l}\text { month f/u participants who } \\
\text { remained in treatment longer } \\
\text { evidenced fewer drug prob- } \\
\text { lems, positive drug screens, } \\
\text { better employment and } \\
\text { fewer psychiatric problems. } \\
\text { No significant differences be- } \\
\text { tween groups at 6-month or } \\
\text { 9-month follow-up. }\end{array}$ \\
\hline
\end{tabular}

${ }^{\mathrm{a} D S M}$ criteria used unless otherwise noted. ${ }^{\mathrm{b}}$ RAAT Random Assignment to Active Treatment, RAWC Random Assignment with Control, PPWC Pre-Post with Comparison Group (matched or otherwise). ${ }^{C} A D$ Alcohol Dependence, $C D$ Cocaine Dependence. Articles included in the review utilized interview diagnosed screening materials (i.e., SCID) to identify drug abuse or dependence. Articles included in this table utilized a control group

CBT [62] or TAU groups [61, 62] at 12 weeks [54], 17 weeks [53], 26 weeks [53] and 52 weeks follow up [51]. Therefore, CBT group therapy and contingency management groups appear to be more effective at reducing cocaine use than TAU groups.

\section{Group-based methamphetamine use treatments for adults}

Only five treatment studies were identified that examined group treatments for methamphetamine use (see Table 3). Three studies found longer periods of abstinence for the group treatment $(\mathrm{CM}$ or drug+CM) than for TAU or non$\mathrm{CM}$ conditions. The first study conducted by Rawson and colleagues compared matrix model (MM) with TAU in eight community outpatient settings [71]. The MM consisted of CBT groups, family education groups, social support groups, and individual counseling sessions along with weekly urine screens for 16 weeks. Participants in the MM condition attended more sessions, stayed in treatment longer, had more than twice as many contacts, evidence longer abstinence and greater self-reported psychosocial functioning relative to the TAU group. However, these significant differences did not persist 6 months later at follow-up.

Shoptaw et al. (2006) [73] compared four groups for treating methamphetamine dependence sertraline $+\mathrm{CM}$, sertraline only, placebo + CM, and placebo [73]. Additionally, all participants attended a relapse prevention group conducted three times a week over a 14-week period. Findings provided support for the efficacy of CM for amphetamine use disorders. Group treatment (CM or drug $+\mathrm{CM}$ ) was more effective for sustaining longer periods of abstinence relative to TAU or non-CM conditions. Roll et al. [72] found that effects of $\mathrm{CM}$ relative to TAU became larger as the duration of $\mathrm{CM}$ increased. Jaffe et al. [70] evaluated a culturally tailored intervention for 145 methamphetamine dependent gay and bisexual males. Participants in the Gay Specific CBT condition reported the most rapid decline in levels of methamphetamine use relative to standard CBT, CBT + $\mathrm{CM}$, suggesting benefits for culturally appropriate group methamphetamine interventions.

\section{Group-based marijuana use treatments for adults}

Two studies examining group treatments for adults with marijuana use disorders were identified (see Table 4). Both studies were conducted by the same research group, utilizing the same inclusion criteria for marijuana use (50 times in 90 days). The studies examined group relapse prevention (RP) [76], specifically designed for adult marijuana users. The first trial [75] $(n=212)$ comparing relapse prevention to a social support group found participants in both group treatment conditions did well overall, with two-thirds (65\%) reporting abstinence of marijuana use for 2 weeks after session 4 or the quit date and $63 \%$ reporting abstinence during the last 2 weeks of treatment. Gender differences emerged; no differences between group treatments were found for women, but men in the relapse prevention group reported reduced marijuana use at the 3-month follow-up compared to men in the social support group.

A second trial [74] randomized participants to 14 sessions of group RP enhanced with cognitive behavioral skills training, two sessions of motivational interviewing (MI) with feedback and advice on cognitive behavioral skills (modeled after the Drinkers Check-up) [77], or a 4-month delayed treatment control (DTC) group which consisted of the RP group or individual MI treatment of the participants choosing. Compared to individuals randomly assigned to the DTC condition, participants in the group RP and individual MI conditions evidenced a significantly greater reduction in marijuana use and related problems over 16-month follow-up. However, examination of participants' reactions to DTC assignment indicated that participants who felt that changing their marijuana use was their own responsibility were more likely than those who did not to change their use patterns without treatment engagement.

\section{Group-based opiate use treatments for adults}

Five group treatment studies for opioid use were identified (see Table 5). Two studies compared the effectiveness of pharmacotherapy plus group therapies [79-81] to pharmacotherapy alone in samples of opioid dependent persons, and both found that adding group 
Table 3 Summary of evidence-based methamphetamine use group treatment for adults

\begin{tabular}{|c|c|c|c|c|c|}
\hline Study & Patient Characteristics $^{\mathrm{a}}$ & Treatment Description & Manual & Study Characteristics ${ }^{b}$ & Results \\
\hline $\begin{array}{l}\text { Jaffe } \\
\text { et al., } \\
2007 \text { [70] }\end{array}$ & $\begin{array}{l}145 \text { methamphetamine- } \\
\text { dependent (DSM-IV) gay and } \\
\text { bisexual males. } \\
\text { Mean age } 37 \text { years, 100\% } \\
\text { male, } 80 \% \text { White, } 12 \% \\
\text { Hispanic. }\end{array}$ & $\begin{array}{l}\text { 1. CBT (control condition; 90- } \\
\text { min group, } 48 \text { session } \\
\text { available) } \\
\text { 2. Contingency management } \\
\text { (CM) (Participants did not } \\
\text { need to attend CBT sessions } \\
\text { they were only provided } \\
\text { vouchers for attending clinic } \\
\text { visits) } \\
\text { 3. CBT + CM (90-min groups + } \\
\text { opportunity to earn vouchers) }\end{array}$ & $\begin{array}{l}\text { 1. Yes } \\
\text { 2. No } \\
\text { 3. Yes } \\
\text { 4. Did } \\
\text { not } \\
\text { report }\end{array}$ & RAWC; No follow up reported. & $\begin{array}{l}\text { Participants' in the "Gay } \\
\text { Specific" CBT condition } \\
\text { reported the most rapid } \\
\text { decline in levels of } \\
\text { methamphetamine use } \\
\text { relative to the other } 3 \\
\text { treatment conditions. } \\
\text { Participants' in the control } \\
\text { condition reported the } \\
\text { highest rates of } \\
\text { methamphetamine use. }\end{array}$ \\
\hline
\end{tabular}

Rawson 978 treatment seeking

et al., individuals with

2004 [71] methamphetamine abuse or

Rawson dependence (DSM-IV

et al., checklist), without medical

2002) detoxification from opioids/

[62]. alcohol/ other drugs. Mean age 33 years, $55 \%$ female, $18 \%$ Hispanic.

Roll et al., 118 participants with

2013 [72] methamphetamine dependence (DSM-IV checklist) without a recent suicide attempt (past 30 days), suicidal ideation, parole status or history of violent criminal behavior, and medical condition that could interfere with treatment
4. "Gay Specific" CBT (90-min group session occurred three times per week)

1. Treatment as usual (TAU; contact with site $1-13 \mathrm{~h}$. per week).

2. Matrix Model (MM; 16weeks; 36 cognitive behavioral therapy groups, 12 family education groups, 4 social sup-

port groups, 4 individual counseling sessions, combined with weekly testing for cocaine, methamphetamine, opiates, cannabis and benzodiazepines. 12-Step meetings encouraged.

\section{Standard psychosocial} Matrix Model

2. ST +1 month of $C M$

3. $S T+2$ months of $C M$

4. ST +4 months of $C M$

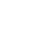
treatment (ST) based on the $37 \%$ completed ST, $67 \%$ completed 1 month of CM, $53 \%$ completed 2 months of CM, 76\% completed 4 months of CM. Post-treatment 4 month $\mathrm{f} / \mathrm{u} ; 42 \%$ for the ST condition, $43 \%$ for the 1 month of CM, $62 \%$ for the 2 month of $C M$, and $64 \%$ for the 4 month CM.

RAWC; post-treatment f/u;

2-week non-medication base- 1.Yes line with 12 weeks of medica- 2. No tion tx and:

3. Yes

$\begin{array}{ll}\text { et al., } & \text { individuals with } \\ 2006 \text { [73] } & \text { methamphetamine abuse or }\end{array}$ dependence (SCID) and without medical condition, current treatment with a selective serotonin reuptake inhibitor, a psychiatric condition, or dependence on opioids, cocaine, alcohol, or benzodiazepines. Mean age 33 years, 38\% female, 23\% Latino.
1. Sertraline plus Contingency Management (S-CM; 4 weekly relapse prevention groups, three times per week)

2. Sertraline-only (S)

3. Placebo medication plus CM (P-CM)

4. Placebo medication (P)
$50.7 \%$ completed all 14 weeks of the trial.

\footnotetext{
${ }^{a}$ DSM criteria used unless otherwise noted. ${ }^{b}$ RAAT Random Assignment to Active Treatment, RAWC Random Assignment with Control, PPWC Pre-Post with Comparison Group (matched or otherwise). Articles included in the review utilized interview diagnosed screening materials (i.e., SCID) to identify drug abuse or dependence. Articles included in this table utilized a control group
} 
Table 4 Summary of evidence-based marijuana use group treatment for adults

\begin{tabular}{|c|c|c|c|c|c|}
\hline Study & Patient Characteristics ${ }^{a}$ & $\begin{array}{l}\text { Treatment } \\
\text { Description }\end{array}$ & Manual & Study Characteristics ${ }^{\mathbf{b}}$ & Results \\
\hline $\begin{array}{l}\text { Stephens } \\
\text { et al. } \\
2000 \text { [74] }\end{array}$ & $\begin{array}{l}291 \text { recruited individuals using } \\
\text { marijuana more than } 50 \text { times in } \\
\text { past } 90 \text { days (questionnaire } \\
\text { screening), without severe } \\
\text { psychological distress, psychosis, } \\
\text { suicidal, cognitive impairments or } \\
\text { formal treatment for marijuana } \\
\text { use. Mean age } 34 \text { years, 23\% } \\
\text { female, 95\% Caucasian. }\end{array}$ & $\begin{array}{l}\text { 1. Relapse } \\
\text { prevention } \\
\text { support group } \\
\text { (RSPG; 14-sessions, } \\
\text { 2 h each, over } 18 \\
\text { weeks). } \\
\text { 2. 2-session motiv- } \\
\text { ational interview- } \\
\text { ing (Ml; Drinkers } \\
\text { Check Up; } 2 \text { 90- } \\
\text { min sessions). } \\
\text { 3. 4-month de- } \\
\text { layed treatment } \\
\text { control (DTC) }\end{array}$ & $\begin{array}{l}\text { 1. Yes } \\
\text { 2. Yes } \\
\text { 2. No }\end{array}$ & $\begin{array}{l}\text { RAWC; 1-, 4-, 7-, 13-, and 16- } \\
\text { month f/u. } 88 \% \text { RSPG f/u rate, } \\
92 \% \mathrm{Ml} \text { f/u rate. Average number } \\
\text { of RPSG treatment sessions was } \\
8.42 \text { out of } 14.86 \% \mathrm{Ml} \text { tx } \\
\text { completion. }\end{array}$ & $\begin{array}{l}\text { Marijuana use, dependence } \\
\text { symptoms, and negative } \\
\text { consequences were reduced } \\
\text { significantly in relation to } \\
\text { pretreatment levels at 1-, 4-, 7-, } \\
13-\text {, and 16-month f/u. RPSG and } \\
\text { Ml evidenced greater improve- } \\
\text { ment than DTC at the 4-month f/ } \\
\text { u. No significant differences be- } \\
\text { tween RPSG and Ml outcomes at } \\
\text { any f/u. }\end{array}$ \\
\hline $\begin{array}{l}\text { Stephens } \\
\text { et al., } \\
1994 \text { [75] }\end{array}$ & $\begin{array}{l}212 \text { recruited participants } \\
\text { reporting using marijuana more } \\
\text { than } 50 \text { times in } 90 \text { days } \\
\text { (questionnaire screening), } \\
\text { without other substance abuse } \\
\text { or dependence, psychosis, or } \\
\text { current treatment for marijuana } \\
\text { use. Mean age } 32 \text { years, } 24 \% \\
\text { female, } 95 \% \text { Caucasian. }\end{array}$ & $\begin{array}{l}\text { 10 2-h sessions: } \\
\text { 1. Relapse } \\
\text { prevention } \\
\text { support group } \\
\text { (RPSG) } \\
\text { 2. Social Support } \\
\text { Group (SSP) }\end{array}$ & $\begin{array}{l}\text { 1. Yes } \\
\text { 2. No }\end{array}$ & $\begin{array}{l}\text { RAAT; } 1-3-6 \text { - and 9-and 12- } \\
\text { month f/u. } 69 \% \text { treatment com- } \\
\text { pletion, } 78 \% \text { f/u rate. }\end{array}$ & $\begin{array}{l}\text { Men in RP were more likely than } \\
\text { men in SSP to report reduced } \\
\text { marijuana use without problems at } \\
\text { 3-month f/u. No other differences } \\
\text { between groups emerged. }\end{array}$ \\
\hline
\end{tabular}

${ }^{\mathrm{a} D S M}$ criteria used unless otherwise noted. ${ }^{\mathrm{b}}$ RAAT Random Assignment to Active Treatment, RAWC Random Assignment with Control, PPWC Pre-Post with Comparison Group (matched or otherwise). Articles included in the review utilized interview diagnosed screening materials (i.e., SCID) to identify drug abuse or dependence. Articles included in this table utilized a control group

treatment improved outcomes. The first study compared Naltrexone with monthly medical monitoring visits to an enhanced group condition (EN) consisting of Naltrexone plus a Matrix Method (MM) [79]. MM consisted of hourly individual sessions, 90-min CBT group, and $60 \mathrm{~min}$ of cue-exposure weekly for weeks 1-12; hourly individual sessions and CBT group sessions for weeks 13-26; and 90-min social support group sessions for weeks 27-52. Results found that EN participants took more study medication, were retained in treatment longer, used less opioids while in treatment, and showed greater improvement on psychological and affective dimensions than Naltrexone only participants. No difference by treatment condition was found at 6- and 12month follow-ups. Similarly, Scherbaum et al. [80] compared routine Methadone Maintenance Therapy (MMT) with routine MMT plus group CBT psychotherapy (20 90-min sessions for 20 weeks). MMT plus group CBT participants showed less drug use than participants in the MMT group (i.e., control group). In contrast, a higher dose of group therapy provided without methadone maintenance was less effective for heroin use than was a lower dose of group therapy with methadone maintenance (Sees et al. [81]. This suggests that the combination of pharmacotherapy and group therapy for opioid use is optimal.

Shaffer et al. [22] compared psychodynamic group therapy with a hatha yoga group. All participants received methadone maintenance and individual therapy. No differences between two treatment conditions were found.
For all participants, longer participation in treatment was associated with reduction in drug use and criminal activity. Lastly, Des Jarlais et al. [78] compared a group social learning AIDS/drug injection treatment program (4 sessions, $60-90 \mathrm{~min}$, over 2 weeks) to a control condition. All participants received information about AIDS and HIV antibody test counseling. Compared to control participants, intervention participants reported lower rates of drug injection over time.

\section{Group treatments for mixed SUD for adults}

Nine treatment studies were identified that targeted mixed substance use with group treatments (see Table 6). Three involved CBT. Downey et al. [82] compared group CBT plus individual CBT to group CBT plus vouchers in a sample of 14 polysubstance users (cocaine and heroin) maintained on buprenorphine. The study was significantly underpowered and they found no significant differences on treatment outcomes. Marques and Formiogioni [84] compared individual CBT to group CBT in a sample of 155 participants with alcohol and/or drug dependence. They found that both formats resulted in similar outcomes, with higher compliance in the group CBT participants $(66.7 \%$ compliance with treatment). Rawson et al. [87] compared three 16-week treatments: $\mathrm{CM}$, group $\mathrm{CBT}$, and $\mathrm{CM}$ plus group $\mathrm{CBT}$, among 171 participants with cocaine disorder or methamphetamine abuse. They found that $\mathrm{CM}$ produced better retention and lower rates of stimulant use than CBT during 
Table 5 Summary of evidence-based opiate use group treatment for adults

\begin{tabular}{|c|c|c|c|c|c|}
\hline Study & Patient Characteristics $^{\mathrm{a}}$ & Treatment Description & Manual & Study Characteristics ${ }^{\mathbf{b}}$ & Results \\
\hline $\begin{array}{l}\text { Des Jarlais } \\
\text { et al., } 1992 \\
\text { [78] }\end{array}$ & $\begin{array}{l}104 \text { individuals who were } \\
\text { using heroin intranasally, } \\
\text { without using more than } 60 \\
\text { injections in past } 2 \text { years } \\
\text { (questionnaire screening). } \\
\text { Mean age } 27 \text { years, 31\% } \\
\text { female, } 27 \% \text { African American, } \\
24 \% \text { Hispanic. }\end{array}$ & $\begin{array}{l}\text { All participants received } \\
\text { information about AIDS, and } \\
\text { HIV antibody test counseling: } \\
\text { 1. Social learning AIDS/drug } \\
\text { injection treatment program } \\
\text { ( } 4 \text { sessions, 60-90 min, over } 2 \\
\text { weeks) } \\
\text { 2. Control condition }\end{array}$ & $\begin{array}{l}\text { 1. Yes } \\
\text { 2. No }\end{array}$ & $\begin{array}{l}\text { RAWC; 8-month f/u. } 80 \% \text { f/u } \\
\text { rate, tx completion rate not } \\
\text { reported. }\end{array}$ & $\begin{array}{l}\text { Control participants reported } \\
\text { higher rates of drug injection } \\
\text { over f/u. }\end{array}$ \\
\hline $\begin{array}{l}\text { Rawson } \\
\text { et al., } 2001 \\
{[79]}\end{array}$ & $\begin{array}{l}81 \text { recruited detoxified } \\
\text { individuals meeting DSM-IV } \\
\text { criteria for opioid dependence } \\
\text { (diagnostic screening measure } \\
\text { not reported). Mean age } 33 \\
\text { years, } 45 \% \text { female, } 80 \% \\
\text { Caucasian. }\end{array}$ & $\begin{array}{l}\text { 1. Standard treatment (ST; } \\
\text { Naltrexone, with monthly } \\
\text { medical monitoring visits). } \\
\text { 2. Enhanced group (EN; Matrix } \\
\text { Method; Naltrexone plus: } \\
\text { Week 1-12 consists of } 60 \text { min } \\
\text { individual sessions } 1 \times \text { week, } \\
90 \text { min. CBT group, and } 60 \\
\text { min cue-exposure; Week 13- } \\
26 \text { consist of individual ses- } \\
\text { sion semi-weekly, and CBT }\end{array}$ & $\begin{array}{l}\text { 1. No } \\
\text { 2. Yes }\end{array}$ & $\begin{array}{l}\text { RAWC; 6-, } 12 \text {-month f/u. } 84 \% \\
\text { f/u and } 87 \% \text { f/u at 6-month } \\
\text { for ST and EN respectively. } 74 \\
\text { and } 79.5 \% \text { f/u at } 12 \text {-month } \\
\text { for SN and EN respectively. Tx } \\
\text { completion not reported }\end{array}$ & $\begin{array}{l}\text { EN group participants took } \\
\text { more study medication, } \\
\text { were retained in treatment } \\
\text { longer, used less opioids } \\
\text { while in treatment and } \\
\text { showed greater improvement } \\
\text { on a number of } \\
\text { psychological/affective } \\
\text { dimensions. No significant } \\
\text { group differences at 6- or 12- } \\
\text { month f/u }\end{array}$ \\
\hline
\end{tabular}

Scherbaum 73 patients at methadone et al., 2005 maintenance treatment with [80] opiate addiction (SCID) and no severe psychiatric condition, psychosis, and organic brain syndrome, serious medical, legal, or social problems. Mean age 30 years, $27 \%$ female, $96 \%$ reported at least 1 parent of German origin.

Sees et al., 179 recruited individuals with 2000 [81] $\quad$ opioid dependence (DIS). Mean age 39 years, $47 \%$ female, 23\% African American in DT, 31\% African American in MMT, $15 \%$ Hispanic in DT, 8\% Hispanic in MMT.

Shaffer 61 referred patients to a et al. (1997) methadone maintenance [22] clinic (screened via "standard assessment battery"), without physical or medical inability to participate in yoga. Mean age 36 years, $41 \%$ female, $82 \%$ Caucasian.

group sessions, and Week 27-

52 consist of 90 min social

support group sessions).

6-months:

1. Local routine MMT

2. Routine MMT plus group

CBT psychotherapy (MMT-CBT;

20 90-min sessions, 20 weeks)

1. No

2. Yes

RAWC; 6-month f/u. f/u rate not reported. $63 \%$ of MMTCBT and $59 \%$ of MMT completed tx. therapy (MMT; $2 \mathrm{~h}$ psychosocial therapy during 1 st 6 months, up to 14 months followed by 2-month detoxification)

2. 180-day Methadone assisted detoxification (DT; $2 \mathrm{~h}$ of psychosocial group therapy per week, 14 weekly substance abuse education sessions, $1 \mathrm{~h}$. of cocaine group therapy for 6 months, weekly individual therapy and 8 months of non-methadone aftercare sessions after 1st 6 months)

22 75-min sessions. All pts. re- 1. Yes ceived methadone treatment 2 . Yes and individual therapy.

1. Psychodynamic group therapy

2. Hatha yoga group
RAAT; 12-week f/u, 74\% f/u rate, $86 \%$ tx completion rate.
RAAT; 6-month f/u. f/u rate not reported. $69 \%$ tx completion.
MMT-CBT showed less drug use than MMT, statistically significant at post treatment and 6-month f/u.
MMT resulted in greater treatment retention and less heroin use compared to DT. Cocaine was related to study dropout in MMT. MMT resulted in lower rate of drug related HIV risk behaviors and lower severity score for legal status. No differences between groups in employment, family functioning, alcohol use.
Longer participation in treatment was associated with reduction in drug use and criminal activity. No difference on any measures between two treatments. 
Table 6 Summary of evidence-based mixed sud group treatment for adults

\begin{tabular}{|c|c|}
\hline Study & Patient Characteristics $^{\mathrm{a}}$ \\
\hline $\begin{array}{l}\text { Downey } \\
\text { et al., } 2000 \\
{[82]}\end{array}$ & $\begin{array}{l}14 \text { buprenophrine } \\
\text { maintained poly-drug users } \\
\text { (cocaine plus heroin). (SCID). } \\
\text { Mean age } 40 \text { years, 39\% fe- } \\
\text { male, 35\% Caucasian. }\end{array}$ \\
\hline $\begin{array}{l}\text { Greenfield } \\
\text { et al., } 2007 \\
\text { [52] }\end{array}$ & $\begin{array}{l}13 \text { (for pilot) and } 31 \text { (in trial) } \\
\text { recruited patients with SUD } \\
\text { (other than nicotine; SCID), } \\
\text { substance use within } 60 \text { days } \\
\text { of baseline, and no need for } \\
\text { medical detoxification, } \\
\text { mandate to treatment, } \\
\text { psychosis, PTSD, concurrent } \\
\text { self-help group treatment. } \\
\text { Mean age } 58 \text { years for GDC } \\
\text { and } 45 \text { for WRG, } 100 \% \text { fe- } \\
\text { male, predominantly } \\
\text { Caucasian. }\end{array}$ \\
\hline
\end{tabular}

Margolin et al., 2003 [83]

Marques \& Formigioni (2001) [84]

McKay et al., 2005 [85]

\section{HIV-seropositive,} methadone-maintained injec tion drug users with opioid dependence, and abuse or dependence on cocaine (screened at intake, utilizing Addiction Severity Index). Mean age 41 years, 30\% female, 48.9\% African American 15.6\% Hispanic

155 recruited alcohol and/or drug dependent patients (standardized assessment interview). Mean age of drug dependent patients 25 years Mean age of AD patients 41 years, $8 \%$ female. No ethnicity data reported.

359 referred patients with $A D$ or CD (SCID). Mean age 42 years, $17 \%$ female, $77 \%$ African American.
Nemes et al., 412 patients in a therapeutic 1999 [86] community with multiple drug/alcohol use dependencies/abuse (SCID. Mean age "mid-thirties", 23\% SC females, 33\% AP females, primarily African American.

\begin{tabular}{|c|c|c|}
\hline Treatment Description & Manual & Study Characteristics ${ }^{b, c}$ \\
\hline $\begin{array}{l}\text { 18 weeks: } \\
\text { 1. Individual CBT ( } 6 \text { sessions) } \\
\text { plus } 12 \text { session (weekly) } \\
\text { group therapy (CBT; relapse } \\
\text { prevention) } \\
\text { 2. CBT based plus vouchers } \\
\text { VBRT) }\end{array}$ & $\begin{array}{l}\text { 1. Yes } \\
\text { 2. Yes }\end{array}$ & $\begin{array}{l}\text { RAAT; post-test at end of 18- } \\
\text { week tx; } 37 \% \text { tx completion/ } \\
\text { f/u rate in CBT; } 65 \% \text { tx com- } \\
\text { pletion/f/u VBRT. }\end{array}$ \\
\hline
\end{tabular}

12 weeks, 90-min sessions, 1x 1. Yes per week:

2. Yes

1. Group Drug Counseling

(GDC; mixed gender; 12

weeks)

2. Women's Recovery Group (WRG; author)

6-months of methadone

maintenance plus:

1. HIV Harm Reduction

Program (HHRP; twice weekly,

2-h groups)

2. Active control that

included harm reduction

components recommended

by the National AIDS

Demonstration Research

Project (six sessions).

17 sessions over 8 months (1 session per week during Month 1-2, 1 session every 2 weeks in Month 3-5, 1 session per month during Month 6-8.

1. Individual CBT (IT;

structured)

2. Group CBT (GT; structured)

12-week continuing care interventions:

1. weekly telephone monitoring and counseling combined with a support group in the first 4 weeks

(TEL);

2. twice-weekly individualized relapse prevention (RP)

3. twice-weekly standard group counseling (STND; 12 step).

12-month program (inpatient 1. No and outpatient):

1. Standard Care (SC, 10 months inpatient, 2 months outpatient)

2. Abbreviated program (AP, 6 months inpatient, 6 months outpatient)

RAWC; 6-month f/u. 87\% f/u rate, $78 \%$ tx completion.
1. Yes

2. Yes

(n)
$71 \%$ 6-month f/u rate, $70 \%$ 9-month f/u rate. $64.4 \%$ tx completion.

1. Yes

2. Yes

RAAT; 15-month f/u. 66\% f/u rate in $\mathrm{IT}, 70 \% \mathrm{f} / \mathrm{u}$ rate in GT. IT attended average of 7 sessions, GT attended average of 8 sessions.

1. Yes

2. Yes

3. Yes

RAAT; 3, 6, 9- and 12-months f/u. $90 \% \mathrm{f} / \mathrm{u}$ rates. The average number of sessions was 14.12 in STND, 14.41 in RP and 10.94 in TEL.

RAWC; 6-month f/u. 93\% f/u rate. SC completed average of 8.2 months of program; AP completed average of 8.6 months of program.

\section{Results}

No significant differences on treatment outcome. Among the subsample that produced one or more poly-drug free urine results, VBRT participants had significantly increased cocaine abstinence.

Pilot testing of WRG evidenced significantly greater reductions in average drinks/drinking day than GDC at 6-month f/u. WRG was equally effective as mixedgender GDC in reducing substance use during the 12week in-treatment phase, but demonstrated significantly greater improvement in reductions in drug and alcohol use over the f/u compared with GDC. Women were significantly more satisfied with WRG than GDC

\section{Both groups showed} reductions in risk behaviors. HHRP evidenced less use of illicit opiates and more adherence to antiretroviral medications; at follow-up, they had lower addiction severity scores and were less likely to have engaged in high risk behavior compared to control.

At follow- up the two formats presented similar outcomes, higher compliance in GT (66.7\%)

Days of abstinence were higher in STND than TEL. Higher scores on a composite risk indicator indicated higher abstinence rates in STND than TEL and lower composite risk scores indicated higher abstinence rates in TEL than STND.

Both groups had reductions in arrests and drug use. No significant differences between groups. 
Table 6 Summary of evidence-based mixed sud group treatment for adults (Continued)

\begin{tabular}{|c|c|c|c|c|c|}
\hline Study & Patient Characteristics $^{\mathrm{a}}$ & Treatment Description & Manual & Study Characteristics ${ }^{b, c}$ & Results \\
\hline $\begin{array}{l}\text { et al., } 2006 \\
\text { [87] }\end{array}$ & $\begin{array}{l}\text { CD or methamphetamine } \\
\text { abuse (SCID), and no AD or } \\
\text { benzodiazepine dependence, } \\
\text { or court mandated to } \\
\text { treatment. Mean age } 36 \text { years, } \\
24 \% \text { female, } 32 \% \text { African } \\
\text { American. }\end{array}$ & $\begin{array}{l}\text { 1. Contingency Management } \\
\text { (CM; vouchers for stimulant- } \\
\text { free urine samples; three } \\
\text { urine samples per week and } \\
\text { meet briefly with the CM } \\
\text { technician) } \\
\text { 2. CBT group (CBT; three 90- } \\
\text { min group sessions each } \\
\text { week, for } 16 \text { weeks). } \\
\text { 3. CM plus CBT groups (CM- } \\
\text { CBT; separate sessions) }\end{array}$ & $\begin{array}{l}\text { 2. Yes } \\
\text { 3. Yes }\end{array}$ & $\begin{array}{l}26 \text { and } 52 \text { f/u. } 81 \% \text { f/u rate. } \\
60 \% \text { CM completed tx, 59\% } \\
\text { CM-CBT completed tx, and } \\
40 \% \text { CBT completed tx. }\end{array}$ & $\begin{array}{l}\text { retention and lower rates of } \\
\text { stimulant use during the } \\
\text { study. Stimulant use was } \\
\text { reduced from baseline levels } \\
\text { at all f/u points for all groups } \\
\text { and urinalysis data did not } \\
\text { differ between groups at f/u. } \\
\text { CM produced evidence of } \\
\text { efficacy during treatment } \\
\text { application, but CBT } \\
\text { produced comparable } \\
\text { longer-term outcomes. There } \\
\text { was no evidence of an addi- } \\
\text { tive effect in CM-CBT. }\end{array}$ \\
\hline $\begin{array}{l}\text { Schottenfeld } \\
\text { et al., } 2000 \\
\text { [88] }\end{array}$ & $\begin{array}{l}117 \text { patients with opioid } \\
\text { dependence and CD or } \\
\text { cocaine abuse (SCID) without } \\
\text { psychosis and not suicidal or } \\
\text { pregnant. Mean age } 34 \text { years, } \\
49 \% \text { female, } 64 \% \text { Caucasian. }\end{array}$ & $\begin{array}{l}\text { In addition to maintenance } \\
\text { medications- } 24 \text { weeks of: } \\
\text { 1. Group Drug Counseling } \\
\text { (GDC; weekly, 1-h } \\
\text { group DC sessions). } \\
\text { 2. Community Reinforcement } \\
\text { Approach (CRA; met in } \\
\text { individual sessions with a } \\
\text { CRA therapist twice weekly } \\
\text { during the first } 12 \text { weeks and } \\
\text { then weekly during the } \\
\text { following } 12 \text { weeks). }\end{array}$ & $\begin{array}{l}\text { 1. Yes } \\
\text { 2. Yes }\end{array}$ & $\begin{array}{l}\text { RAAT; 9-week ff/u. No f/u } \\
\text { rate reported. Tx completion } \\
\text { for GDC was } 59.6 \text { and } 61.7 \% \\
\text { for the CRA. }\end{array}$ & $\begin{array}{l}\text { There were no significant } \\
\text { differences in retention or } \\
\text { drug use. The total number } \\
\text { of hours and average hours } \\
\text { per week engaged in } \\
\text { nondrug-related activities } \\
\text { was higher for CRA patients } \\
\text { who achieved abstinence } \\
\text { from opioids, cocaine, or } \\
\text { both combined. }\end{array}$ \\
\hline $\begin{array}{l}\text { Smith et al., } \\
1999 \text { [89] }\end{array}$ & $\begin{array}{l}383 \text { inpatient veterans, } \\
\text { meeting } A D, C D \text { or } \\
\text { amphetamine dependence } \\
\text { (Semi-structured interview). } \\
\text { Mean age } 40-50 \text { years, } 0 \% \\
\text { female, } 11-46 \% \text { of } \\
\text { participants in each group } \\
\text { were African American. }\end{array}$ & $\begin{array}{l}\text { Between } 21 \text { and } 28 \text { days of } \\
\text { treatment: } \\
\text { 1. Standard treatment } \\
\text { program (STP; daily group } \\
\text { counseling, family outreach, } \\
\text { 12-step program introduc- } \\
\text { tion, four 2-h. sessions for } \\
\text { family) } \\
\text { 2. Enhanced treatment } \\
\text { program (ETP; } 10 \mathrm{~h} \text {. per week, } \\
\text { twice weekly groups on } \\
\text { relapse prevention and } \\
\text { interpersonal counseling) }\end{array}$ & $\begin{array}{l}\text { 1. No } \\
\text { 2. Yes }\end{array}$ & $\begin{array}{l}\text { 1st cohort completed STP; } \\
\text { 2nd cohort completed ETP; } \\
\text { 3- and 12-month f/u. } 92 \% \mathrm{f} / \mathrm{u} \\
\text { rate at 3-month and } 83 \% \mathrm{f} / \mathrm{u} \\
\text { at } 12 \text {-month. } 80 \% \text { tx } \\
\text { completion. }\end{array}$ & $\begin{array}{l}\text { ETP evidenced enhanced } \\
\text { abstinence rates at 3-month } \\
\text { and } 12 \text {-month follow-up } \\
\text { compared to STP, regardless } \\
\text { of type of drug use. }\end{array}$ \\
\hline
\end{tabular}

${ }^{a}$ DSM criteria used unless otherwise noted. ${ }^{\mathrm{b}}$ RAAT Random Assignment to Active Treatment, RAWC Random Assignment with Control, PPWC Pre-Post with Comparison Group (matched or otherwise). 'AD Alcohol Dependence, $C D$ Cocaine Dependence, SUD Substance Use Disorder. Articles included in the review utilized interview diagnosed screening materials (i.e., SCID) to identify drug abuse or dependence. Articles included in this table utilized a control group

treatment, but CBT produced comparable longer-term outcomes.

Two studies involved Group Drug Counseling (GDC). Greenfield et al. [52] compared a group drug counseling (GDC) (mixed gender) to a women's recovery group (WRG) that both met weekly, for 12 weeks, for 90-min sessions among 44 participants that had a substance use disorder other than nicotine. WRG evidenced significantly greater reductions in drug and alcohol use over the follow up compared with GDC. Schottenfeld et al. [88] compared GDC (weekly, 1-h group sessions) to a community reinforcement approach (CRA; twice weekly sessions for the first 12 weeks and then weekly the following 12 weeks) among 117 patients with an opioid and cocaine use disorder. There were no differences in retention or drug use.

Remaining studies examined other interventions. Margolin et al. [83] compared an HIV Harm reduction program (HHRP) that met twice weekly for $2 \mathrm{~h}$ to an active control group that met six times in a sample of 90 HIV-seropositive methadone-maintained injection drug users with opioid dependence, and abuse or dependence on cocaine. At follow up, they had lower addiction severity scores and were less likely to have engaged in high risk behaviors compared to control. McKay et al. [85] compared weekly phone monitoring and counseling plus a support group in the first 4 weeks (TEL), twice-weekly individualized relapse prevention, and twice-weekly standard group counseling (STND) among 259 referred participants with alcohol use disorder or cocaine disorder. STND resulted in more days abstinent than TEL. Nemes et al. [86] compared a 12-month group program (10 months inpatient and 2 months outpatient) to an abbreviated group program (6 months inpatient, 6 months outpatient) among 412 patients with multiple drug/alcohol use disorders. Results indicated that both groups had 
reduction in arrests and drug use. There were no significant difference between groups. Lastly, Smith et al. [89] compared a standard treatment program (STP, daily group counseling, family outreach, 12-step program introduction, four $2 \mathrm{~h}$ sessions for family) to an enhanced treatment program (ETP; twice weekly group on relapse prevention and interpersonal violence in additional to all STP components) among 383 inpatient veterans meeting for an alcohol, cocaine, or amphetamine use disorder. Results indicated that ETP had enhanced abstinence rates at 3-month and 12-month follow up compared to STP, regardless of type of drug use.

\section{Group Treatments for SUD and Co-Occurring Psychiatric Problems}

Individuals with psychiatric distress are at high risk for comorbid SUD [90]. Ten randomized controlled studies meeting our inclusion criteria examined the efficacy of group therapy for SUD and co-occurring psychiatric problems (see Table 7). Three studies described group treatment of SUD and co-occurring DSM-IV Axis II disorders $[18,91,96]$, three studies examined group treatment of drug abuse and co-occurring DSM-IV classified Axis I disorders [92, 93, 99], one study explored group drug abuse treatment and co-occurring psychiatric problems among homeless individuals without limiting to DSM-IV Axis I or Axis II diagnoses [97], and one study focused on group drug treatment among individuals testing positive for HIV [98]. Within this diverse set of RCTs, participants generally included individuals diagnosed with any form of SUD; however, some studies focused specifically on individuals using cocaine [91, 97] or cocaine/opioids [98].

A range of group treatment approaches are represented, including group psychoeducational therapy, group CBT approaches, group DBT, Seeking Safety and CM. DiNitto and colleagues [92] evaluated the efficacy of adding a group-based psychoeducational program entitled "Good Chemistry Groups" to standard inpatient SUD treatment services among 97 individuals with a dual diagnosis of SUD and a DSM-IV Axis I psychological disorder. The nine 60-min Good Chemistry Group sessions were offered 3 times per week for 3 weeks. When compared to standard inpatient treatment, the addition of the psychoeducational group was not associated with any changes in medical, legal, alcohol, drug, psychiatric or family/social problems among participants.

The efficacy of adding a psychoeducational group treatment to standard individual therapy to address HIV risk among cocaine users has also been examined [91]. Participants were randomly assigned to complete the following: 1) individually-administered Standard Intervention developed by the NIDA Cooperative Agreement
Final Cohort sites [100] including HIV testing, and preand post-HIV testing counseling on risks relating to cocaine use, transmission of STDs/HIV, condom use, cleaning injection equipment, and the benefits of treatment; or) Standard Intervention plus four 2-h peerdelivered psychoeducational groups addressing stress management, drug awareness, risk reduction strategies, HIV education and AIDS. Among the sample of 966 individuals completing the 3-month follow-up, the group psychoeducational treatment was not differentially effective in reducing drug use and HIV risk behavior in comparison to standard treatment alone at 3-months post-baseline, regardless of treatment type, individuals with antisocial personality disorder (ASPD) demonstrated less improvement in crack cocaine use compared to individuals without ASPD or depression.

The following types of group CBT have sustained research evaluation meeting our inclusion criteria to address co-occurring SUD and Axis I or Axis II disorders: 1) group behavioral skills training; 2) group cognitive behavioral therapy; 3) group-based Seeking Safety [51], and 4) group dialectical behavioral therapy. Specifically, Jerrell and Ridgely [93] examined the efficacy of group behavioral skills (BS) training, group-based 12-step facilitation (TS) treatment, and intensive case management among 132 individuals with a dual diagnosis of SUD and another Axis I psychiatric problem over the course of 24-months. Based on the Social and Independent Living Skills program [101], the BS group included one group per week addressing self-management skills designed to enhance abstinence, including medication management, relapse prevention, social skills, leisure activities and symptom monitoring. Relative to participants in TS groups, participants in the BS groups evidenced increased psychosocial functioning and decreased psychiatric symptoms (i.e., schizophrenia, depressive symptoms, mania, drug use and alcohol use) across the 6-, 12- and 18-month follow-up assessments after treatment entry.

Lehman and colleagues' [95] examination of the efficacy of group CBT for substance abuse compared to TAU among 54 individuals with SUD and either schizophrenia or a major affective disorder revealed no differences between treatment groups over the course of a 1-year follow-up period. More promising findings were reported in Fisher and Bentley's [18] evaluation of a group CBT and group therapy based in the disease and recovery model (DRM) among 38 individuals with dual diagnosis of SUD and a personality disorder. Groups met three times per week for 12 weeks and were compared to TAU. Individuals in group CBT and group DRM indicated improved social and family functioning compared to TAU, and among those who completed the group in an outpatient setting, CBT was more effective in reducing 
Table 7 Summary of evidence-based drug abuse disorders and co-occurring psychiatric problems group treatment for adults

\begin{tabular}{|c|c|c|c|c|c|}
\hline Study & Patient Characteristics $^{\mathrm{a}}$ & Treatment Description & Manual & Study Characteristics ${ }^{b, c}$ & Results \\
\hline $\begin{array}{l}\text { Compton } \\
\text { et al., } \\
2000 \text { [91] }\end{array}$ & $\begin{array}{l}996 \text { recruited outpatient } \\
\text { cocaine users with and } \\
\text { without antisocial personality } \\
\text { disorder (ASPD) and major } \\
\text { depression (DIS). Mean age } 39 \\
\text { years, 39\% female, 92\% African } \\
\text { American. }\end{array}$ & $\begin{array}{l}\text { Two 15-min sessions, plus } 4 \\
\text { peer-administered 2-h } \\
\text { sessions: } \\
\text { 1. Standard Intervention (Sl; } \\
\text { developed by NIDA } \\
\text { Cooperative Agreement Final } \\
\text { Cohort sites; } 2 \text { 15-min } \\
\text { sessions) } \\
\text { 2. Enhanced Intervention (El; } \\
\text { SI plus 4-peer administered 2- } \\
\text { h sessions) }\end{array}$ & $\begin{array}{l}\text { 1. Yes } \\
\text { 2. Yes }\end{array}$ & $\begin{array}{l}\text { RAAT; 3-month follow-up. } \\
88 \% \text {, f/u rate, 100\% participa- } \\
\text { tion in SI, } 69 \% \text { tx completion } \\
\text { in El. }\end{array}$ & $\begin{array}{l}\text { All groups improved } \\
\text { significantly in: crack cocaine } \\
\text { use, injection drug use (IDU), } \\
\text { number of IDU sex partners } \\
\text { and overall number of sex } \\
\text { partners. Stratified by } \\
\text { psychiatric status, ASPD was } \\
\text { associated with significantly } \\
\text { less improvement in crack } \\
\text { cocaine use. When } \\
\text { examining the standard and } \\
\text { peer groups separately, no } \\
\text { consistent differences in the } \\
\text { association of psychiatric } \\
\text { comorbidity with outcome } \\
\text { were evidenced. }\end{array}$ \\
\hline
\end{tabular}

\begin{tabular}{|c|c|}
\hline $\begin{array}{l}\text { DiNitto } \\
\text { et al., } \\
2002 \text { [92] }\end{array}$ & $\begin{array}{l}97 \text { recruited inpatients at } \\
\text { chemical dependency } \\
\text { treatment program, with Axis I } \\
\text { disorder (ASI, Addiction } \\
\text { Severity Index). Mean age } 33 \\
\text { years, 53\% female, 28\% African } \\
\text { American. }\end{array}$ \\
\hline $\begin{array}{l}\text { Fisher \& } \\
\text { Bentley } \\
(1996) \\
{[18]}\end{array}$ & $\begin{array}{l}38 \text { referred inpatient and } \\
\text { outpatient with SUD and } \\
\text { personality disorder (SCID). } \\
\text { Mean age } 37 \text { years, } 24 \% \\
\text { female } 61 \% \text { African America }\end{array}$ \\
\hline
\end{tabular}

Jerrell $\quad 132$ recruited outpatients with et al., $\quad$ psychotic or Axis I disorder 1995 [93]; and SUD (DIS) and poor work Jerrell history; eligibility for public et al., assistance, poor basic living 1997 [94] skills, poor social support, or poor social skills. Excluded based on cognitive impairment, personality disorder and medical disabilities. Ages 28-59, 23\% female, no ethnicity data provided.

Lehman 54 patients with SUD and et al., schizophrenia or affective 1993 [95] disorder (SCID). Mean age 30 years, $26 \%$ female, $79 \%$ African American.

Linehan 27 referred from community et al. care, with borderline 1999 [96] personality disorder and SUD (opiates, cocaine, amphetamines, sedatives, hypnotics, anxiolytics, or 28-days of treatment:

1. No 1. Treatment as usual (TAU;

2. Yes

Inpatient chemical

dependency services)

2. Good Chemistry Group

(GCG; TAU plus

psychoeducational group therapy; 9 60-min sessions; 3 times a week; repeated for 15 months)

45-min sessions, $3 \times$ per week, 1. Yes for 4 weeks:

2. Yes

1. Disease-recovery group

(DRG; acceptance of sub-

stance abuse as a chronic and progressive disease)

2. CBT-group

3. Group treatment as usual (Control)

1. Twelve-step group (TS; one 1. Yes to several meetings per week; 2. Yes structured)

2. Behavioral Skills group (BS;

Social and Independent Skills program; one group per week)

3. Intensive case management (Program for Assertive Community Treatment; as needed 5 day/ week)

5 1-h sessions and 2 months of intensive case

management:

1. Treatment as usual

(Control; Community mental health center and rehabilitation services) 2. Being sober group, plus group and intensive casemanagement (ICM-G)

Weekly 1 -h individual sessions; 2-h group sessions; coaching as needed for 12 months:

1. Treatment as usual (TAU; outpatient psychotherapy or

RAWC; 1-. 2- and 3-month f/u. No significant differences $86 \% \mathrm{f} / \mathrm{u}$ rate. Average treatment 25.6 days for GCG and 26.3 days for TAU.

RAWC; Full sample completed pre and post-test assessments (e.g. 100\% tx completion and f/u rate).

$$
\text { between groups. }
$$

DRG and CBT evidenced improved social/family relations compared to control. CBT more effective than DRG group in reducing alcohol and improving social/family function and enhancing psychological function.

RAAT. 18-month f/u. No data provided on $\mathrm{f} / \mathrm{u}$ rate or $\mathrm{tx}$ completion rate.

1. No 2. Yes

RAWC; 1 year $f / u$, No f/u rate reported. $20 \%$ average tx attendance.

RAWC; 16-month f/u; 66\% f/u rate, $70 \%$ tx completion rate.
BS and ICM evidenced significant decreases in schizophrenia, depression and mania symptoms compared to TS. BS also evidenced significant decreases in drug and alcohol use compared to TS. Compared to men, women had higher functioning scores, more psychiatric symptomatology, and greater reductions in use of acute treatment services used over the 6-month f/u.

One-year follow-ups detected no significant differences between ICM-G and Control (treatment as usual).
DBT evidenced greater reductions in drug use compared to TAU throughout treatment and at f/u. DBT evidenced significantly higher tx retention compared to TAU, 
Table 7 Summary of evidence-based drug abuse disorders and co-occurring psychiatric problems group treatment for adults (Continued)

\begin{tabular}{|c|c|c|c|c|c|}
\hline Study & Patient Characteristics $^{a}$ & Treatment Description & Manual & Study Characteristics $^{b, c}$ & Results \\
\hline & $\begin{array}{l}\text { polysubstance use; SCID and } \\
\text { International Personality } \\
\text { Disorders Exam). Mean age } 30 \\
\text { years, 100\% female, } 78 \% \\
\text { Caucasian. }\end{array}$ & $\begin{array}{l}\text { community care). } \\
\text { 2. Dialectical Behavior } \\
\text { Therapy Group modified for } \\
\text { substance use (DBT). }\end{array}$ & & & $\begin{array}{l}\text { and greater global adjustment } \\
\text { at follow-up compared to } \\
\text { TAU. }\end{array}$ \\
\hline $\begin{array}{l}\text { Milby } \\
\text { et al., } \\
2004 \text { [97] }\end{array}$ & $\begin{array}{l}\text { 141recruited cocaine- } \\
\text { dependent homeless individ- } \\
\text { uals and co-occurring non- } \\
\text { psychotic mental disorder } \\
\text { (DSM-III-R checklist). Mean age } \\
\text { 38, 72\% male, } 83 \% \text { African } \\
\text { American. }\end{array}$ & $\begin{array}{l}\text { All participants received: } \\
\text { Phase I ( } 8 \text { weeks day } \\
\text { treatment, } 5 \text { days per week, } \\
5.5 \text { h per day; highly } \\
\text { structured) and Phase II (16 } \\
\text { weeks of weekly group } \\
\text { therapy, individual counseling } \\
1 \text { time per week). } \\
\text { 1. Day treatment only (DT) } \\
\text { 2. Day treatment plus } \\
\text { abstinent-contingent housing } \\
\text { and work (DT+) }\end{array}$ & $\begin{array}{l}\text { 1. Yes } \\
\text { 2. Yes }\end{array}$ & $\begin{array}{l}\text { RAAT; } 2-\text {, 6-, and } 12-\text { month f/ } \\
\text { u. At 2-months, } 76.3 \% \text { f/u, at } \\
\text { 6-months, } 74.5 \% \text { f/u. } 37 \% \text { tx } \\
\text { completion in DT, } 77 \% \text { of DT+ } \\
\text { tx completion. }\end{array}$ & $\begin{array}{l}\text { Compared with DT, more DT+ } \\
\text { participants established } \\
\text { abstinence, maintained } \\
\text { abstinence for longer } \\
\text { durations, were marginally } \\
\text { significantly more likely to } \\
\text { lapse, and significantly less } \\
\text { likely to relapse. Of all } \\
\text { participants who established } \\
\text { abstinence and then relapsed, } \\
\text { DT+participants relapsed later } \\
\text { and were more likely to } \\
\text { reestablish abstinence. }\end{array}$ \\
\hline $\begin{array}{l}\text { Petry } \\
\text { et al. } \\
(2010) \\
{[98]}\end{array}$ & $\begin{array}{l}170 \text { HIV+ patients with } \\
\text { cocaine or opioid abuse or } \\
\text { dependence over past year } \\
\text { (via SCID). Mean age } 43 \text { years, } \\
\text { 39\% female, } 44 \% \text { African } \\
\text { American, 32\% Hispanic. }\end{array}$ & $\begin{array}{l}\text { Weekly groups for } 24 \text { weeks: } \\
\text { 1.Contingency management } \\
\text { (CM) } \\
\text { 2.Twelve step groups (TS) }\end{array}$ & $\begin{array}{l}\text { 1. Yes } \\
\text { 2. Yes }\end{array}$ & $\begin{array}{l}\text { RAAT; } 1-, 3-, 6-, 9-\text { and } 12- \\
\text { month f/u; mean attendance } \\
10.8 \text { for CM and } 9 \text { for TS. }\end{array}$ & $\begin{array}{l}\text { Compared to TS, CM } \\
\text { participants submitted more } \\
\text { consecutive drug-free urine } \\
\text { specimens; whereas negative } \\
\text { urine samples did not vary be- } \\
\text { tween groups during treat- } \\
\text { ment or follow-up; CM } \\
\text { participants reported fewer } \\
\text { HIV-risk behaviors compared } \\
\text { to TS during treatment. }\end{array}$ \\
\hline $\begin{array}{l}\text { Zlotnick } \\
\text { et al. } \\
(2009) \\
{[99]}\end{array}$ & $\begin{array}{l}49 \text { incarcerated women with } \\
\text { SUD and full/subthreshold } \\
\text { posttraumatic stress disorder } \\
\text { (SCID and Clinician Assisted } \\
\text { Posttraumatic Stress Disorder } \\
\text { Scale-I) without psychotic or } \\
\text { organic brain impairment. } \\
\text { Mean age } 35 \text { years, 100\% fe- } \\
\text { male, 32.7\% African American, } \\
\text { 14.2\% Hispanic. }\end{array}$ & $\begin{array}{l}\text { 6-8-week intervention: } \\
\text { 1. Treatment as usual (TAU; } \\
\text { 180-240 h of individual and } \\
\text { group treatment) } \\
\text { 2. Seeking Safety Group (90- } \\
\text { min sessions, 3x per week) }\end{array}$ & $\begin{array}{l}\text { 1. No } \\
\text { 2. Yes }\end{array}$ & $\begin{array}{l}\text { RAWC; } 12 \text {-week, 3-, and 6- } \\
\text { month f/u. 97\% 12-week f/u } \\
\text { rate, } 85 \% \text { 6-month f/u rate for } \\
\text { SS, and } 95 \% 6-\text { month f/u rate } \\
\text { for TAU. Women attended } \\
\text { average of } 15.6 \text { of } 25 \text { SS } \\
\text { sessions. }\end{array}$ & $\begin{array}{l}\text { Consistent main effects for } \\
\text { time but not group by time } \\
\text { interaction on key variables } \\
\text { (e.g., PTSD, substance use, } \\
\text { legal problems). } 6 \text { months } \\
\text { after release from prison, 53\% } \\
\text { of the women in both groups } \\
\text { reported a remission of PTSD. } \\
\text { Some advantages for Seeking } \\
\text { Safety were found over TAU } \\
\text { during the f/u period (e.g., } \\
\text { improvement in } \\
\text { psychopathology and } \\
\text { recidivism rates). }\end{array}$ \\
\hline
\end{tabular}

${ }^{a}$ DSM criteria used unless otherwise noted. ${ }^{b}$ RAAT Random Assignment to Active Treatment, RAWC Random Assignment with Control, PPWC Pre-Post with Comparison Group (matched or otherwise). 'AD Alcohol Dependence, CD Cocaine Dependence, SUD Substance Use Disorder. Articles included in the review utilized interview diagnosed screening materials (i.e., SCID) to identify drug abuse or dependence. Articles included in this table utilized a control group

alcohol use, enhancing psychological functioning and improving social and family functioning compared to DRM and TAU.

Group behavioral therapy plus abstinence contingent housing and work administered in the context of a day treatment program was compared to behavioral group treatment alone among individuals with cocaine abuse/ dependence, non-psychotic psychiatric conditions, and homelessness [97, 102]. The group behavioral therapy included 8 weeks of daily treatment $(4 \mathrm{~h}$ and $50 \mathrm{~min}$ per day) of groups addressing relapse prevention training, assertiveness training, AIDS education, 12-step facilitation, relaxation, recreation development, goal setting, and goal planning. Participants also engaged in a process-oriented group as well as individual counseling and urine monitoring and engaged in a weekly $90 \mathrm{~min}$ psychoeducational group therapy during months 3-6 following treatment enrollment. Individuals who received contingency-based work and housing were provided with rent-free housing and employment in construction or food service industries after 2 consecutive weeks of abstinence [103]. Relative to BS groups alone, group behavioral day treatment plus contingency management was associated with greater abstinence at 2- and 6-month follow-ups [102] and were less likely to relapse [97], although gains were not maintained at 12- 
months [104]. Both groups evidenced positive changes in drug use overtime compared to baseline [104].

Zlotnick, Johnston and Najavits [99] evaluated the efficacy of Seeking Safety (SS), in comparison to treatment as usual (TAU) among 49 incarcerated women with substance use disorder (SUD) and full or subthreshold posttraumatic stress disorder (PTSD). SS aims to decrease PTSD and SUD through psychoeducational and presentfocused and empowerment-based instruction on coping skills that emphasize abstinence and safety [51]. The SS group treatment included 90-min group sessions held three times per week, that were completed in addition to the 180 to $240 \mathrm{~h}$ of group and individual therapy provided in TAU. All participants showed similar improvement on assessments of PSTD, SUD, legal problems and other psychiatric concerns at 12-week, 3- and 6-month follow-ups following prison release. Nonetheless, there was a trend for improved PTSD and continued improvements in psychiatric symptoms at follow-up among participants completing SS compared to TAU. Greater completion of SS sessions was associated with increased improvement in PTSD as well as drug use among women [99].

Dialectical behavioral group therapy (DBT), a CBTfocused treatment for individuals with borderline personality disorder (BPD), has also been evaluated in comparison to TAU among individuals with BPD and cooccurring SUD [96]. Core elements of DBT are manualized [105], and have been evaluated in prior research [106-108]. Techniques center on providing the participant with acceptance and validation while maintaining a continual focus on behavior change, and include the following: mindfulness skills training, behavioral analysis of dysfunctional behavior, cognitive restructuring, coping skills training, exposure-based strategies addressing maladaptive emotions, and behavioral management skills training. DBT was administered through $2 \frac{1}{4}$ hour weekly group sessions administered in combination with 60 min of weekly individual therapy and the opportunity for skills-coaching phone calls. Relative to TAU, participants randomly assigned to DBT demonstrated greater reductions in drug use during the 12-month treatment and at the 16-month follow-up assessment, as well as greater gains in adjustment at the 16-month follow-up assessment.

Although contingency management is commonly administered individually, Petry and colleagues [98] examined the efficacy of weekly 60-min group-based contingency management $(\mathrm{CM})$ for reinforcing health behaviors and HIV-positive individuals with cocaine or opioid disorders $(N=170)$ in comparison to 12-step facilitation (TS) over the course of a 24-week period. Overall, participants in CM were more likely than those in TS to submit consecutive drug-free urine specimens, although the overall proportion of drug-free specimens did not vary between groups during treatment or over the follow-up period. Notably, during treatment, group CM was associated with greater reductions in HIV-risk behaviors as well as overall viral load compared to TS; although effects were not maintained over the follow-up period.

Across these studies, many trials showed positive gains for both group treatments examined $[18,97,98]$, or no difference between groups when examining the benefit of adding group treatment to existing TAU [91, 92, 95, 99]. However, one study demonstrated greater reductions in drug use among individuals with BPD and SUD who completed group DBT in comparison to TAU [96]. Further, BS groups were more effective than TS groups in improving psychosocial functioning and decreasing substance use [93]. Finally, CBT was more effective than DRM in reducing alcohol use, enhancing psychological functioning and improving social and family functioning compared to DRM and TAU among individuals dually diagnosed with SUD and a personality disorder [18].

\section{Factors associated with treatment efficacy Gender and treatment efficacy}

Five of the studies included in the present review examined whether treatment was differentially effective for men and women. Although Jarrell and Ridgely's [93] evaluation of group BS, group TS and individual case management for individuals with SUD and co-occurring Axis I disorders did not examine whether group treatment types were differentially effective for men and women, data indicated that women-regardless of treatment group-reported higher role functioning (i.e.., independent living, work productivity, as well as immediate and extended social relationships), increased psychiatric symptomatology (depression, mania, drug use, alcohol use) across the follow-up periods compared to men.

\section{Race and ethnicity and treatment efficacy}

Among the studies included in the present review, only three examined whether treatment efficacy varied as a function of race and ethnicity. A secondary examination of the efficacy of group BS in comparison to group TS and individual case management [93] suggested that outcomes in each group treatment among ethnic and racial minority clients were equivalent to White participants during the 6-month follow [94]. The initial evaluation indicated that-regardless of group treatment type-racial/ethnic minority participants reported lower scores in personal well-being, lower life satisfaction (i.e., satisfaction with living), worse role functioning (i.e., independent living, work productivity, immediate and extended social relationships) over the follow-up periods compared to White participants [93]. 


\section{Conclusions}

In general, participants in group treatment for drug use disorders exhibit more improvement on typical measures of outcome (e.g., abstinence \& use rates, objective measures, urinalysis) when compared to standard care without group $[18,109]$ and those who refuse or drop out of treatment [110]. Specifically, CBT and CM appear to be more effective at reducing cocaine use than TAU groups. CM is effective in increasing periods of abstinence among users of methamphetamine. Both relapse prevention and social support group therapy were effective for marijuana use although relapse prevention was more helpful for men than for women. Brief MI and relapse prevention were both effective at reducing marijuana use. CBT and CBT-related treatments (including the matrix model) when added to pharmacotherapy were more effective for opioid use disorder than pharmacotherapy alone. Effective treatments for Mixed SUD include group CBT, CM, and women's recovery group. Longer relapse prevention periods appear to be more helpful in reducing mixed SUD. Behavioral skills and behavioral skills plus contingency management helped decreased psychiatric symptoms and drug use behaviors. Psychoeducation groups alone, a commonly used intervention, were not effective at addressing SUD and co-occurring psychiatric problems. Additionally, it is important to note that there is potential for risk of bias in the studies included across four domains: participants, predictors, outcome, and analysis [111]. The current study did not comprehensively assess for risk of bias and this is a study limitation. Future research could assess for risk of bias by following the guidelines suggested by the Cochrane Handbook [112].

The current literature offers a wide variety of group treatments with varying goals and based on varying formal change theories. Overall, studies that reported between-group effect size $(n=7)$ reported small to medium effect sizes potentially suggesting differences were moderate but of potential theoretical interest. Of those seven studies, only two studies reported large effect sizes (both comparing an active treatment to a delayed treatment/untreated condition). In order to better characterize magnitude of intervention effects, future studies should report effect sizes and their confidence intervals [113, 114]. Moreover, groups based on cognitive-behavioral theory [35], motivational enhancement theory [43], stages of change theory [115], 12-step theory [41] and psychoeducational group models [116] have all been the subject of recent studies. Steps of treatment have also been used to classify groups for acutely ill individuals with SUD versus middle stage (recovering) or after care groups, with the latter mainly focusing on relapse prevention. Group therapy is provided - at least as an augment to multimodal interventions - in most of the outpatient and inpatient programs in English speaking and European countries [17, 117]. Therefore, continued efforts to implement and scale up group-based treatments for SUD known to be effective are needed. $\mathrm{CM}$ appears to be effective at addressing various drug use problems and further research should evaluate whether it would also be useful for marijuana use.

\section{Future Research Questions}

- Studies of other group treatments for SUD that use rigorous, interview-based diagnosis, use control groups, randomly assign participants to condition, report the ethnic and racial composition of the sample, are adequately powered, implement a treatment manual, and compare outcomes to individual treatment as well are necessary.

- Little is known regarding the possible mediators and moderators of treatment outcome in group interventions for SUD

\section{Key Learning Objectives}

- Group treatment approaches are widely utilized and are often less costly to implement than individual treatments, currently we know very little whether one group approach is superior to another in the treatment of SUD.

- Group treatment approaches seem to be more effective at improving positive outcomes (e.g., abstinence, use rates, objective measures, urinalysis) when compared to standard care without group [18, 109], and those who refuse and drop out of treatment

- More thorough randomized controlled trials of group SUD treatments are needed [110].

\section{Abbreviations}

12SG: Twelve Step Facilitation Group Therapy; AD: Alcohol Dependence: AIDS: Acquired Immunodeficiency Syndrome; ASI: Addiction Severity Index; ASPD: Antisocial Personality Disorder; AP: Abbreviated Program; BS: Behavioral Skills; BPD: Borderline Personality Disorder; CBT: Cognitive Behavioral Therapy; CD: Cocaine Dependence; CIDI: Composite Diagnostic Interview Schedule; CM: Contingency Management; CRA: Community Reinforcement Approach; CS: Coping Skills; CT: Cognitive Therapy; DBT: Dialectical Behavioral Therapy; DT: Day Treatment; DC: Drug Counseling; DIS: Diagnostic Interview Schedule; DSM: Diagnostic and Statistical Manual; DRM: Disease and Recovery Model; DTCL: Delayed to Control; EBP: EvidenceBased Practice; EBT: Evidence-Based Treatment Practice; EN: Enhanced Group Condition; ETP: Enhanced Treatment Program; FT: Family Therapy;

GDC: Group Drug Counseling; HIV: Human Immunodeficiency Virus; HHRP: HIV Harm Reduction; HR: Harm Reduction; IGT: Intensive Group Therapy; IT: Individual Therapy; MI: Motivational Interviewing; MM: Matrix Model; MMT: Methadone Maintenance Therapy; NIDA: National Institute of Drug Abuse; PET: Psychoeducational Therapy Group; PPWC: Pre-Post with Comparison Group (matched or otherwise); PTSD: Post Traumatic Stress Disorder; RAWC: Random Assignment with Control; RP: Relapse Prevention; RT: Recovery Training; RAAT: Random Assignment to Active Treatment; RPMG: Relational Psychotherapy Mothers' Group; SCID: Structured Clinical Interview for Diagnosis; SS: Social Support; SGT: Standard Group Therapy; 
SUD: Substance Use Disorder; SS: Seeking Safety; STND: Standard Group Counseling; STP: Standard Treatment Program; TAU: Treatment as Usual; TEL: Phone Monitoring and Counseling, with Support Group; TPC: Therapeutic Community Program; TS: Twelve Step; WRG: Women's Recovery Group

\section{Acknowledgements}

The authors have no acknowledgements.

\section{Authors' contributions}

All authors participated in the review of manuscripts included in the study, writing of sections of the manuscript, as well as final editing of the paper. All authors read and approved the final manuscript.

\section{Funding}

The study is not supported through funding.

\section{Availability of data and materials}

Not applicable. The present study does not include original data. However, the authors of the study have listed all articles reviewed in this study in the reference section.

\section{Declarations}

\section{Ethics approval and consent to participate}

Not applicable.

\section{Consent for publication}

Not applicable.

\section{Competing interests}

The authors declare that they have no competing interests.

\section{Author details}

${ }^{1}$ Center for Alcohol and Addiction Studies, Brown University, Providence, Rl 02912, USA. ${ }^{2}$ Alpert Medical School of Brown University, Department of Psychiatry and Human Behavior, Providence, RI 02904, USA. ${ }^{3}$ Walter Reed Army Institute of Research, Silver Spring, MD 20910, USA. ${ }^{4}$ Massachusetts General Hospital, Harvard Medical School, Boston, MA 02115, USA. ${ }^{5}$ Division of Public Health, Michigan State University, Flint, Ml 48502, USA.

\section{Accepted: 3 April 2021}

Published online: 21 June 2021

\section{References}

1. Grant BF, Saha TD, Ruan WJ, Goldstein RB, Chou SP, Jung J, et al. Epidemiology of DSM-5 drug use disorder: results from the National Epidemiologic Survey on alcohol and related conditions-III. JAMA Psychiatry. 2016;73(1):39-47.

2. Edition F. Diagnostic and statistical manual of mental disorders: DSM-5 ${ }^{\mathrm{TM}}$. 5th ed; 2013.

3. Rehm J, Marmet S, Anderson P, Gual A, Kraus L, Nutt DJ, et al. Defining substance use disorders: do we really need more than heavy use? Alcohol Alcohol. 2013;48(6):633-40.

4. Birnbaum HG, White AG, Schiller M, Waldman T, Cleveland JM, Roland CL. Societal costs of prescription opioid abuse, dependence, and misuse in the United States. Pain Med. 2011;12(4):657-67.

5. Center NDI. National Drug Threat Assessment. Washington: United States Department of Justice; 2011

6. Florence CS, Zhou C, Luo F, Xu L. The economic burden of prescription opioid overdose, abuse, and dependence in the United States, 2013. Med Care. 2016;54(10):901-6.

7. Kamal R, Cox C, Rousseau D, Foundation ftKF. Costs and outcomes of mental health and substance use disorders in the US. JAMA. 2017;318(5): 415.

8. Hall WD, Patton G, Stockings E, Weier M, Lynskey M, Morley Kl, et al. Why young people's substance use matters for global health. Lancet Psychiatry. 2016;3(3):265-79.

9. Khalsa JH, Treisman G, McCance-Katz E, Tedaldi E. Medical consequences of drug abuse and co-occurring infections: research at the National Institute on Drug Abuse. Subst Abus. 2008;29(3):5-16.
10. McCoy CB, Lai S, Metsch LR, Messiah SE, Zhao W. Injection drug use and crack cocaine smoking: independent and dual risk behaviors for HIV infection. Ann Epidemiol. 2004;14(8):535-42.

11. Contoreggi, md C, Rexroad, rph VE, Lange, md, et al. Current Management of Infectious Complications in the injecting drug user. J Subst Abus Treat. 1998;15(2):95-106.

12. Sackett DL, Rosenberg WMC, Gray JAM, Haynes RB, Richardson WS. Evidence based medicine: what it is and what it isn't. BMJ. 1996;312(7023): $71-2$.

13. American Psychological Association PTFoE-BP. Evidence-based practice in psychology. Am Psychol. 2006;61:271-85.

14. Pope C. Resisting evidence: the study of evidence-based medicine as a contemporary social movement. Health. 2003;7(3):267-82.

15. Wendt D. Group therapy for substance use disorders: a survey of clinician practices. J Groups Addict Recover. 2017;12(4):243 EOA.

16. Johnson J. Using research-supported group treatments. J Clin Psychol In Session. 2008:64(11):1206-24

17. Stinchfield RD, Owen P, Winters K. Group therapy for substance abuse: A review of the empirical research. In: Burlingame AFG, editor. Handbook of group psychotherapy. New York: Wiley; 1994. p. 458-88.

18. Fisher MS Sr, Bentley KJ. Two group therapy models for clients with a dual diagnosis of substance abuse and personality disorder. Psychiatr Serv. 1996; 47(11):1244-50.

19. Kaminer Y, Burleson JA, Blitz C, Sussman J, Rounsaville BJ. Psychotherapies for adolescent substance abusers: a pilot study. J Nerv Ment Dis. 1998; 186(11):684-90.

20. McKay JR, Alterman Al, Cacciola JS, O'Brien CP, Koppenhaver JM, Shepard DS. Continuing care for cocaine dependence: comprehensive 2-year outcomes. J Consult Clin Psychol. 1999;67(3):420-7.

21. McKay JR, Alterman Al, Cacciola JS, Rutherford MJ, O'Brien CP, Koppenhaver J. Group counseling versus individualized relapse prevention aftercare following intensive outpatient treatment for cocaine dependence: initia results. J Consult Clin Psychol. 1997;65(5):778-88.

22. Shaffer HJ, LaSalvia TA, Stein JP. Comparing hatha yoga with dynamic group psychotherapy for enhancing methadone maintenance treatment: a randomized clinical trial. Altern Ther Health Med. 1997;3(4):57-66.

23. Morgan-Lopez AA, Fals-Stewart W. Analytic methods for modeling longitudinal data from rolling therapy groups with membership turnover. J Consult Clin Psychol. 2007;75(4):580-93.

24. Weiss RD. Treating patients with bipolar disorder and substance dependence: lessons learned. J Subst Abus Treat. 2004;27(4):307-12.

25. Lundahl BW, Kunz C, Brownell C, Tollefson D, Burke BL. A meta-analysis of motivational interviewing: twenty-five years of empirical studies. Res Soc Work Pract. 2010;20(2):137-60.

26. Weiss RD, Jaffee WB, de Menil VP, Cogley CB. Group therapy for substance use disorders: what do we know? Harvard Rev Psychiatry. 2004;12(6):339-50.

27. Burlingame GM, MacKenzie KR, Strauss B. Bergin \& Garfields Handbook Of Psychotherapy And Behavior Change. Small group treatment: Evidence for effectiveness and mechanisms of change. In: Lambert M, editor. Handbook of psychotherapy and behavior change. 5th ed. New York: Wiley; 2003. p. 647-96.

28. Beck AT. Cognitive therapy: nature and relation to behavior therapy. Behav Ther. 1970;1(2):184-200.

29. Guydish J, Sorensen JL, Chan M, Werdegar D, Bostrom A, Acampora A. A randomized trial comparing day and residential drug abuse treatment: 18month outcomes. J Consult Clin Psychol. 1999;67(3):428-34.

30. Guydish J, Werdegar D, Sorensen JL, Clark W, Acampora A. Drug abuse day treatment: a randomized clinical trial comparing day and residential treatment programs. J Consult Clin Psychol. 1998;66(2):280-9.

31. Avants SK, Margolin A, Sindelar JL, Rounsaville BJ, Schottenfeld R, Stine S, et al. Day treatment versus enhanced standard methadone services for opioiddependent patients: a comparison of clinical efficacy and cost. Am J Psychiatry. 1999;156(1):27-33.

32. Avants SK, Margolin A, Usubiaga MH, Doebrick C. Targeting HIV-related outcomes with intravenous drug users maintained on methadone: a randomized clinical trial of a harm reduction group therapy. J Subst Abus Treat. 2004;26(2):67-78.

33. Maude-Griffin PM, Hohenstein JM, Humfleet GL, Reilly PM, Tusel DJ, Hall SM. Superior efficacy of cognitive-behavioral therapy for urban crack cocaine abusers: main and matching effects. J Consult Clin Psychol. 1998;66(5):8327. 
34. Rohsenow DJ, Monti PM, Martin RA, Michalec E, Abrams DB. Brief coping skills treatment for cocaine abuse: 12-month substance use outcomes. J Consult Clin Psychol. 2000;68(3):515-20.

35. Beck ATW, F. D.; Newman, C. F.; Liese, B. S. Cognitive therapy of substance abuse. New York: Guilford; 1993.

36. McAuliffe WE. A randomized controlled trial of recovery training and selfhelp for opioid addicts in New England and Hong Kong. J Psychoactive Drugs. 1990;22(2):197-209.

37. Czuchry M, Dansereau DF. Node-link mapping and psychological problems. Perceptions of a residential drug abuse treatment program for probationers. J Subst Abus Treat. 1999;17(4):321-9.

38. McCusker J, Bigelow C, Frost R, Garfield F, Hindin R, Vickers-Lahti M, et al. The effects of planned duration of residential drug abuse treatment on recovery and HIV risk behavior. Am J Public Health. 1997;87(10):1637-44.

39. Rosenblum A, Magura S, Kayman DJ, Fong C. Motivationally enhanced group counseling for substance users in a soup kitchen: a randomized clinical trial. Drug Alcohol Depend. 2005;80(1):91-103.

40. Marlatt GA, Donovan DM. Relapse prevention: Maintenance strategies in the treatment of addictive behaviors. 2nd ed. New York: The Guilford Press; 2005. p. xiv, 416-xiv

41. Crits-Christoph P, Siqueland L, Blaine J, Frank A, Luborsky L, Onken LS, et al. Psychosocial treatments for cocaine dependence: National Institute on Drug Abuse collaborative cocaine treatment study. Arch Gen Psychiatry. 1999. 56(6):493-502.

42. Luthar SSS, N.E.; Altomare, M. Relational psychotherapy Mother's group: A randomized clinical trial for substance abusing mothers. Dev Psychopathol. 2007;19:243-61.

43. Miller WRR, S. Motivational interviewing: preparing people to change addictive behavior. New York: Guilford Press; 1991.

44. Hoffman JA, Caudill BD, Koman JJ 3rd, Luckey JW, Flynn PM, Mayo DW. Psychosocial treatments for cocaine abuse. 12-month treatment outcomes. J Subst Abus Treat. 1996;13(1):3-11.

45. Kaminer Y, Burleson JA, Goldberger R. Cognitive-behavioral coping skills and psychoeducation therapies for adolescent substance abuse. J Nerv Ment Dis. 2002;190(11):737-45.

46. Linehan M. DBT skills training manual. 2nd ed. London: The Guilford Press; 2015.

47. Petry NM. Contingency management: what it is and why psychiatrists should want to use it. Psychiatrist. 2011;35(5):161-3.

48. Logan DE, Marlatt GA. Harm reduction therapy: a practice-friendly review of research. J Clin Psychol. 2010;66(2):201-14.

49. Ellis B, Bernichon T, Yu P, Roberts T, Herrell JM. Effect of social support on substance abuse relapse in a residential treatment setting for women. Eva Program Plan. 2004;27(2):213-21.

50. Nowinski J, Baker S. The twelve-step facilitation handbook: A systematic approach to early recovery from alcoholism and addiction. San Francisco: Jossey-Bass; 1992. p. xxii. 215-xxii

51. Najavits LM. Seeking safety: a treatment manual for PTSD and substance abuse. New York: Guilford; 2002.

52. Greenfield SF, Trucco EM, McHugh RK, Lincoln M, Gallop RJ. The Women's recovery group study: a stage I trial of women-focused group therapy for substance use disorders versus mixed-gender group drug counseling. Drug Alcohol Depend. 2007;90(1):39-47.

53. Liddle HA, Dakof GA, Parker K, Diamond GS, Barrett K, Tejeda M. Multidimensional family therapy for adolescent drug abuse: results of a randomized clinical trial. Am J Drug Alcohol Abuse. 2001;27(4):651-88.

54. Coviello DM, Alterman Al, Rutherford MJ, Cacciola JS, McKay JR, Zanis DA. The effectiveness of two intensities of psychosocial treatment for cocaine dependence. Drug Alcohol Depend. 2001;61(2):145-54.

55. Crits-Christoph P, Siqueland L, McCalmont E, Weiss RD, Gastfriend DR, Frank A, et al. Impact of psychosocial treatments on associated problems of cocaine-dependent patients. J Consult Clin Psychol. 2001; 69(5):825-30.

56. Siqueland L, Crits-Christoph P, Gallop R, Barber JP, Griffin ML, Thase ME, et al. Retention in psychosocial treatment of cocaine dependence: predictors and impact on outcome. Am J Addict. 2002;11(1):24-40.

57. Mercer D, Carpenter G, Daley D. The adherence and competence scale for group addiction counseling for TCACS: Center for Psychotherapy Research Department of Psychiatry, University of Pennsylvania Medical School; 1994.

58. Luborsky L. Principles of psychoanalytic psychotherapy a manual for supportive-expressive treatment; 1984.
59. Epstein DH, Hawkins WE, Covi L, Umbricht A, Preston KL. Cognitivebehavioral therapy plus contingency management for cocaine use: findings during treatment and across 12-month follow-up. Psychol Addict Behav. 2003;17(1):73-82.

60. Magura S, Rosenblum A, Lovejoy M, Handelsman L, Foote J, Stimmel B. Neurobehavioral treatment for cocaine-using methadone patients: a preliminary report. J Addict Dis. 1994;13(4):143-60.

61. Petry NM, Alessi SM, Hanson T. Contingency management improves abstinence and quality of life in cocaine abusers. J Consult Clin Psychol. 2007;75(2):307-15.

62. Rawson RA, Huber A, McCann M, Shoptaw S, Farabee D, Reiber C, et al. A comparison of contingency management and cognitive-behavioral approaches during methadone maintenance treatment for cocaine dependence. Arch Gen Psychiatry. 2002;59(9):817-24.

63. Rohsenow DJ, Monti PM, Rubonis AV, Gulliver SB, Colby SM, Binkoff JA, et al. Cue exposure with coping skills training and communication skills training for alcohol dependence: 6- and 12-month outcomes. Addiction. 2001;96(8): 1161-74.

64. Rosenblum A, Magura S, Foote J, Palij M, Handelsman L, Lovejoy M, et al. Treatment intensity and reduction in drug use for cocaine-dependent methadone patients: a dose-response relationship. J Psychoactive Drugs. 1995;27(2):151-9.

65. Rosenblum A, Magura S, Palij M, Foote J, Handelsman L, Stimmel B. Enhanced treatment outcomes for cocaine-using methadone patients. Drug Alcohol Depend. 1999;54(3):207-18.

66. Volpicelli JR, Markman I, Monterosso J, Filing J, O'Brien CP. Psychosocially enhanced treatment for cocaine-dependent mothers: evidence of efficacy. J Subst Abus Treat. 2000;18(1):41-9.

67. Weinstein SP, Gottheil E, Sterling RC. Randomized comparison of intensive outpatient vs. individual therapy for cocaine abusers. J Addict Dis. 1997; 16(2):41-56

68. Gottheil E, Weinstein SP, Sterling RC, Lundy A, Serota RD. A randomized controlled study of the effectiveness of intensive outpatient treatment for cocaine dependence. Psychiatr Serv. 1998;49(6):782-7.

69. Magura S, Rosenblum A, Fong C, Villano C, Richman B. Treating cocaineusing methadone patients: predictors of outcomes in a psychosocial clinical trial. Subst Use Misuse. 2002;37(14):1927-55.

70. Jaffe A, Shoptaw S, Stein J, Reback CJ, Rotheram-Fuller E. Depression ratings, reported sexual risk behaviors, and methamphetamine use: latent growth curve models of positive change among gay and bisexual men in an outpatient treatment program. Exp Clin Psychopharmacol. 2007;15(3):301-7.

71. Rawson RA, Marinelli-Casey P, Anglin MD, Dickow A, Frazier Y, Gallagher C, et al. A multi-site comparison of psychosocial approaches for the treatment of methamphetamine dependence. Addiction. 2004;99(6):708-17.

72. Roll JM, Chudzynski J, Cameron JM, Howell DN, McPherson S. Duration effects in contingency management treatment of methamphetamine disorders. Addict Behav. 2013;38(9):2455-62.

73. Shoptaw S, Huber A, Peck J, Yang X, Liu J, Jeff D, et al. Randomized, placebo-controlled trial of sertraline and contingency management for the treatment of methamphetamine dependence. Drug Alcohol Depend. 2006; 85(1):12-8.

74. Stephens RS, Roffman RA, Curtin L. Comparison of extended versus brief treatments for marijuana use. J Consult Clin Psychol. 2000;68(5):898-908.

75. Stephens RS, Roffman RA, Simpson EE. Treating adult marijuana dependence: a test of the relapse prevention model. J Consult Clin Psychol. 1994;62(1):92-9.

76. Marlatt GAG, J.R. Relapse prevention (unpublished manuscript). In: Luther SSS, Boltas D, editors. Relational parenting Mother's group: A therapist's manual. New York: Guilford Press; 1985.

77. Miller WR, Benefield RG, Tonigan JS. Enhancing motivation for change in problem drinking: a controlled comparison of two therapist styles. J Consult Clin Psychol. 1993;61(3):455-61.

78. Des Jarlais DC, Casriel C, Friedman SR, Rosenblum A. AIDS and the transition to illicit drug injection--results of a randomized trial prevention program. $\mathrm{Br}$ J Addict. 1992;87(3):493-8.

79. Rawson RA, McCann MJ, Shoptaw SJ, Miotto KA, Frosch DL, Obert JL, et al. Naltrexone for opioid dependence: evaluation of a manualized psychosocial protocol to enhance treatment response. Drug Alcohol Rev. 2001;20(1):67-78.

80. Scherbaum N, Kluwig J, Specka M, Krause D, Merget B, Finkbeiner T, et al. Group psychotherapy for opiate addicts in methadone maintenance treatment--a controlled trial. Eur Addict Res. 2005;11(4):163-71. 
81. Sees KL, Delucchi KL, Masson C, Rosen A, Clark HW, Robillard H, et al. Methadone maintenance vs 180-day psychosocially enriched detoxification for treatment of opioid dependence: a randomized controlled trial. JAMA. 2000;283(10):1303-10.

82. Downey KK, Helmus TC, Schuster CR. Treatment of heroin-dependent polydrug abusers with contingency management and buprenorphine maintenance. Exp Clin Psychopharmacol. 2000;8(2):176-84.

83. Margolin A, Avants SK, Warburton LA, Hawkins KA, Shi J. A randomized clinical trial of a manual-guided risk reduction intervention for HIV-positive injection drug users. Health Psychol. 2003;22(2):223-8.

84. Marques AC, Formigoni ML. Comparison of individual and group cognitivebehavioral therapy for alcohol and/or drug-dependent patients. Addiction. 2001;96(6):835-46.

85. McKay JR, Lynch KG, Shepard DS, Morgenstern J, Forman RF, Pettinati HM. Do patient characteristics and initial progress in treatment moderate the effectiveness of telephone-based continuing care for substance use disorders? Addiction. 2005;100(2):216-26.

86. Nemes S, Wish ED, Messina N. Comparing the impact of standard and abbreviated treatment in a therapeutic community. Findings from the district of Columbia treatment initiative experiment. J Subst Abus Treat. 1999;17(4):339-47.

87. Rawson RA, McCann MJ, Flammino F, Shoptaw S, Miotto K, Reiber C, et al. A comparison of contingency management and cognitive-behavioral approaches for stimulant-dependent individuals. Addiction. 2006;101(2):26774.

88. Schottenfeld RS, Pantalon MV, Chawarski MC, Pakes J. Community reinforcement approach for combined opioid and cocaine dependence. Patterns of engagement in alternate activities. J Subst Abus Treat. 2000; 18(3):255-61.

89. Smith TL, Volpe FR, Hashima JN, Schuckit MA. Impact of a stimulant-focused enhanced program on the outcome of alcohol- and/or stimulantdependent men. Alcohol Clin Exp Res. 1999;23(11):1772-9.

90. Regier DA, Farmer ME, Rae DS, Locke BZ, Keith SJ, Judd LL, et al. Comorbidity of mental disorders with alcohol and other drug abuse: results from the epidemiologic catchment area (ECA) study. JAMA. 1990;264(19): 2511-8.

91. Compton WM, Cottler LB, Ben-Abdallah A, Cunningham-Williams R, Spitznagel EL. The effects of psychiatric comorbidity on response to an HIV prevention intervention. Drug Alcohol Depend. 2000;58(3):247-57.

92. DiNitto DM, Webb DK, Rubin A. Gender differences in dually-diagnosed clients receiving chemical dependency treatment. J Psychoactive Drugs. 2002:34(1):105-17.

93. Jerrell JM, Ridgely MS. Comparative effectiveness of three approaches to serving people with severe mental illness and substance abuse disorders. Nerv Ment Dis. 1995;183(9):566-76.

94. Jerrell JM, Wilson JL. Ethnic differences in the treatment of dual mental and substance disorders. A preliminary analysis. J Subst Abus Treat. 1997;14(2): 133-40.

95. Lehman AF, Herron JD, Schwartz RP, Myers CP. Rehabilitation for adults with severe mental illness and substance use disorders. A clinical trial. J Nerv Ment Dis. 1993;181(2):86-90.

96. Linehan MM, Schmidt H 3rd, Dimeff LA, Craft JC, Kanter J, Comtois KA. Dialectical behavior therapy for patients with borderline personality disorder and drug-dependence. Am J Addict. 1999;8(4):279-92.

97. Milby JB, Schumacher JE, Vuchinich RE, Wallace D, Plant MA, Freedman MJ, et al. Transitions during effective treatment for cocaine-abusing homeless persons: establishing abstinence, lapse, and relapse, and reestablishing abstinence. Psychol Addict Behav. 2004;18(3):250-6.

98. Petry NM, Weinstock J, Alessi SM, Lewis MW, Dieckhaus K. Group-based randomized trial of contingencies for health and abstinence in HIV patients. J Consult Clin Psychol. 2010;78(1):89-97.

99. Zlotnick C, Johnson J, Najavits LM. Randomized controlled pilot study of cognitive-behavioral therapy in a sample of incarcerated women with substance use disorder and PTSD. Behav Ther. 2009:40(4):325-36.

100. Wechsberg WM, MacDonald BR, Dennis ML, Inciardi JA, Surratt HL, Leukefeld CG, et al. The standard intervention for reduction in HIV risk behavior; protocol changes suggested by the continuing HIV/AIDS epidemic. Bloomington: Lighthouse Institute; 1997.

101. Liberman RP, Massel HK, Mosk MD, Wong SE. Social skills training for chronic mental patients. Hosp Community Psychiatry. 1985;36(4):396-403.
102. Milby JB, Schumacher JE, McNamara C, Wallace D, Usdan S, McGill T, et al. Initiating abstinence in cocaine abusing dually diagnosed homeless persons. Drug Alcohol Depend. 2000;60(1):55-67.

103. Milby JB, Schumacher JE, Raczynski JM, Caldwell E, Engle M, Michael M, et al. Sufficient conditions for effective treatment of substance abusing homeless persons. Drug Alcohol Depend. 1996:43(1-2):39-47.

104. Milby JB, Schumacher JE, Wallace D, Frison S, McNamara C, Usdan S, et al. Day treatment with contingency management for cocaine abuse in homeless persons: 12-month follow-up. J Consult Clin Psychol. 2003;71(3): 619-21.

105. Linehan MMD, L.A. Dialectical behavior therapy manual of treatment interventions for drug abusers with borderline personality disorder. Seattle: University of Washington; 1997.

106. Linehan MM, Heard HL, Armstrong HE. Naturalistic follow-up of a behavioral treatment for chronically parasuicidal borderline patients. Arch Gen Psychiatry. 1993;50(12):971-4.

107. Linehan MM, Tutek DA, Heard HL, Armstrong HE. Interpersonal outcome of cognitive behavioral treatment for chronically suicidal borderline patients. Am J Psychiatry. 1994;151(12):1771-6.

108. Linehan MM, Armstrong HE, Suarez A, Allmon D, Heard HL. Cognitivebehavioral treatment of chronically parasuicidal borderline patients. Arch Gen Psychiatry. 1991;48(12):1060-4.

109. Burtscheidt W, Schwarz R, Redner C, Gaebel W. Behavioral therapeutic methods in ambulatory treatment of alcoholism. Early results of an experimental study. Fortschr Neurol Psychiatr. 1999;67(6):274-80.

110. Sandahl C, Herlitz K, Ahlin G, Rönnberg S. Time-limited group psychotherapy for moderately alcohol dependent patients: A randomized controlled clinical trial. Psychother Res. 1998;8(4):361-78.

111. Wolff RF, Moons KG, Riley RD, Whiting PF, Westwood M, Collins GS, et al. PROBAST: a tool to assess the risk of bias and applicability of prediction model studies. Ann Intern Med. 2019;170(1):51-8.

112. Higgins JP, Savović J, Page MJ, Elbers RG, Sterne JA. Assessing risk of bias in a randomized trial. In: Cochrane handbook for systematic reviews of interventions; 2019. p. 205-28.

113. Diener MJ. The Corsini Encyclopedia of Psychology; 2010. p. 1.

114. Schulz KF, Altman DG, Moher D. CONSORT 2010 statement: updated guidelines for reporting parallel group randomised trials. Trials. 2010;11(1):18.

115. Prochaska JO, DiClemente CC. Stages of change in the modification of problem behaviors. Prog Behav Modif. 1992;28:183-218.

116. Drake RE, McLaughlin P, Pepper B, Minkoff K. Dual diagnosis of major mental illness and substance disorder: an overview. New Dir Ment Health Serv. 1991;1991(50):3-12.

117. Kunzke D, Strauss B, Burtscheidt W. The effectiveness of psychodynamic group therapy in the treatment of alcohol abuse. A review. Gruppenpsychotherapie und Gruppendynamik. 2002;38:53-70.

\section{Publisher's Note}

Springer Nature remains neutral with regard to jurisdictional claims in published maps and institutional affiliations.

Ready to submit your research? Choose BMC and benefit from:

- fast, convenient online submission

- thorough peer review by experienced researchers in your field

- rapid publication on acceptance

- support for research data, including large and complex data types

- gold Open Access which fosters wider collaboration and increased citations

- maximum visibility for your research: over $100 \mathrm{M}$ website views per year

At BMC, research is always in progress.

Learn more biomedcentral.com/submission 